\title{
Predicting the denitrification capacity of sandy aquifers from in situ measurements using push-pull ${ }^{15} \mathrm{~N}$ tracer tests
}

\author{
W. Eschenbach ${ }^{1}$, R. Well ${ }^{1}$, and W. Walther ${ }^{* * * *}$ \\ ${ }^{1}$ Johann Heinrich von Thünen-Institut, Federal Research Institute for Rural Areas, Forestry and Fisheries, \\ Institute of Climate-Smart Agriculture, Bundesallee 50, 38116 Braunschweig, Germany \\ * formerly at: Institute for Groundwater Management, Dresden University of Technology, 01062 Dresden, Germany \\ ** retired \\ Correspondence to: W. Eschenbach (w.eschenbach@gmx.de)
}

Received: 21 October 2014 - Published in Biogeosciences Discuss.: 2 December 2014

Revised: 5 March 2015 - Accepted: 10 March 2015 - Published: 17 April 2015

\begin{abstract}
Knowledge about the spatial variability of in situ denitrification rates $\left(D_{\mathrm{r}}\right.$ (in situ $\left.)\right)$ and their relation to the denitrification capacity in nitrate-contaminated aquifers is crucial to predict the development of groundwater quality. Therefore, 28 push-pull ${ }^{15} \mathrm{~N}$ tracer tests for the measurement of in situ denitrification rates were conducted in two sandy Pleistocene aquifers in northern Germany.

The ${ }^{15} \mathrm{~N}$ analysis of denitrification-derived ${ }^{15} \mathrm{~N}$-labelled $\mathrm{N}_{2}$ and $\mathrm{N}_{2} \mathrm{O}$ dissolved in water samples collected during the push-pull ${ }^{15} \mathrm{~N}$ tracer tests was performed using isotope ratio mass spectrometry (IRMS) in the lab and additionally for some tracer tests online in the field with a quadrupole membrane inlet mass spectrometer (MIMS) in order to test the feasibility of on-site real-time ${ }^{15} \mathrm{~N}$ analysis. Aquifer material from the same locations and depths as the push-pull injection points was incubated, and the initial and cumulative denitrification after 1 year of incubation $\left(D_{\text {cum }}(365)\right)$ as well as the stock of reduced compounds (SRC) was compared with in situ measurements of denitrification. This was done to derive transfer functions suitable to predict $D_{\text {cum }}(365)$ and SRC from $D_{\mathrm{r}}$ (in situ).

$D_{\mathrm{r}}$ (in situ) ranged from 0 to $51.5 \mu \mathrm{g} \mathrm{N} \mathrm{kg}-1 \mathrm{~d}^{-1}$. Denitrification rates derived from on-site isotope analysis using MIMS satisfactorily coincided with laboratory analysis by conventional IRMS, thus proving the feasibility of in situ analysis. $D_{\mathrm{r}}$ (in situ) was significantly higher in the sulfidic zone of both aquifers compared to the zone of non-sulfidic aquifer material. Overall, regressions between the $D_{\text {cum }}(365)$ and SRC of the tested aquifer material with $D_{\mathrm{r}}$ (in situ) exhibited only a modest linear correlation for the full data
\end{abstract}

set. However, the predictability of $D_{\text {cum }}(365)$ and SRC from $D_{\mathrm{r}}$ (in situ) data clearly increased for aquifer samples from the zone of $\mathrm{NO}_{3}^{-}$-bearing groundwater.

In the $\mathrm{NO}_{3}^{-}$-free aquifer zone, a lag phase of denitrification after $\mathrm{NO}_{3}^{-}$injections was observed, which confounded the relationship between reactive compounds and in situ denitrification activity. This finding was attributed to adaptation processes in the microbial community after $\mathrm{NO}_{3}^{-}$injections. It was also demonstrated that the microbial community in the $\mathrm{NO}_{3}^{-}$-free zone just below the $\mathrm{NO}_{3}^{-}$-bearing zone can be adapted to denitrification by $\mathrm{NO}_{3}^{-}$injections into wells for an extended period. In situ denitrification rates were 30 to 65 times higher after pre-conditioning with $\mathrm{NO}_{3}^{-}$. Results from this study suggest that such pre-conditioning is crucial for the measurement of $D_{\mathrm{r}}$ (in situ) in deeper aquifer material from the $\mathrm{NO}_{3}^{-}$-free groundwater zone and thus for the prediction of $D_{\text {cum }}(365)$ and SRC from $D_{\mathrm{r}}$ (in situ).

\section{Introduction}

Denitrification, the microbially mediated reduction of nitrate $\left(\mathrm{NO}_{3}^{-}\right)$and nitrite $\left(\mathrm{NO}_{2}^{-}\right)$to the nitrogen gasses nitric oxide $(\mathrm{NO})$, nitrous oxide $\left(\mathrm{N}_{2} \mathrm{O}\right)$ and dinitrogen $\left(\mathrm{N}_{2}\right)$, is important to water quality and chemistry at landscape, regional and global scales (Groffman et al., 2006). $\mathrm{NO}_{3}^{-}$is quantitatively the most abundant reactive nitrogen $\left(\mathrm{Nr}^{1}\right)$ species. Diffuse $\mathrm{NO}_{3}^{-}$emissions from the agricultural sector are the 
dominant source of $\mathrm{Nr}$ fluxes to aquifers. ${ }^{1}$ Denitrification in aquifers, reviewed, for example, by Korom (1992), Hiscock et al. (1991), Burgin and Hamilton (2007), and Rivett et al. (2008), ranges from 0 to $100 \%$ of total $\mathrm{NO}_{3}^{-}$input, with high spatial variability (Seitzinger et al., 2006). This leads to the question of how individual aquifers will respond to the anthropogenic $\mathrm{NO}_{3}^{-}$pollution in groundwater. This problem depends not only on how rates of denitrification will respond to $\mathrm{Nr}$ loading (Seitzinger et al., 2006) but also on where and how long denitrification in aquifers can remediate $\mathrm{NO}_{3}^{-}$pollution (Kölle et al., 1985). Continuous $\mathrm{NO}_{3}^{-}$input via seepage water leads to ongoing exhaustion of the reductive capacity of aquifers. This can be a problem for keeping $\mathrm{NO}_{3}^{-}$in drinking water below the limit of $50 \mathrm{mg} \mathrm{L}^{-1}$ (Drinking Water Directive 98/83/EC) and can also be problematic due to possible eutrophication of surface waters (Vitousek et al., 1997). However $\mathrm{NO}_{3}^{-}$can also mobilise deposits of uranium (U) in aquifers, which can be mobilised if $\mathrm{NO}_{3}^{-}$reaches reduced aquifer zones (Senko et al., 2002; Istok et al., 2004). Therefore, knowledge about the denitrification capacity of aquifers is needed to predict the possible development of groundwater quality.

The presented study continues previous research on denitrification rates measured in two sandy Pleistocene aquifers in northern Germany (Fuhrberger Feld aquifer (FFA) and the aquifer of Großenkneten (GKA)). Frind et al. (1990) reported that, due to lithotrophic denitrification, $\mathrm{NO}_{3}^{-}$has a half-life of 1 to 2 years in the deeper zone (below 5 to $10 \mathrm{~m}$ ) of the wellinvestigated FFA. Weymann et al. (2010) reported very low denitrification rates with values as low as $4 \mu \mathrm{g} \mathrm{N} \mathrm{kg}^{-1} \mathrm{~d}^{-1}$ in the uppermost groundwater, in the organotrophic denitrification zone of the same aquifer. In a recent study, Eschenbach and Well (2013) measured median denitrification rates of 15.1 and $9.6 \mathrm{mg} \mathrm{N} \mathrm{kg}^{-1} \mathrm{yr}^{-1}$ during 1 year of anaerobic incubations of FFA and GKA aquifer samples, with significantly higher denitrification rates in the deeper parts of both aquifers. This study showed that the cumulative denitrification after prolonged incubation of aquifer samples is correlated with the stock of reduced compounds (SRC). Similar results had been obtained earlier for other aquifers in northern Germany (Konrad, 2007). While we found close correlations between initial laboratory denitrification rates and the $\mathrm{SRC}$ in aquifer zones where $\mathrm{NO}_{3}^{-}$is present in groundwater, samples from the $\mathrm{NO}_{3}^{-}$-free groundwater zone showed a time lag of denitrification of several weeks during incubations (Eschenbach and Well, 2013), possibly due to the initial absence of denitrifying enzymes. These findings demonstrate that the SRC can be estimated from denitrification rates if the

\footnotetext{
${ }^{1}$ The term reactive nitrogen is used in this work in accordance with Galloway et al. (2004) and includes all biologically or chemically active $\mathrm{N}$ compounds like reduced forms (e.g. $\mathrm{NH}_{3}, \mathrm{NH}_{4}^{+}$), oxidized forms (e.g. $\mathrm{NO}_{\mathrm{x}}, \mathrm{HNO}_{3}, \mathrm{~N}_{2} \mathrm{O}, \mathrm{NO}_{3}^{-}$) and organic compounds (e.g. urea, amines, proteins).
}

microbial community is adapted to denitrification (Eschenbach and Well, 2013).

In situ denitrification rates can be measured using singlewell push-pull tests where a test solution containing solutes of interest is rapidly injected into a well (push phase) and process information is obtained from analysing the mixture of groundwater and test solution collected during the subsequent pull phase. These tests, perhaps first used for in situ measurement of denitrification rates by Trudell et al. (1986), have proven to be a relatively low-cost technique to obtain quantitative information about several aquifer properties. This method has been applied in a variety of studies to derive in situ denitrification rates indirectly by the measurement of $\mathrm{NO}_{3}^{-}$depletion during push-pull tests (Trudell et al., 1986; Istok et al., 1997, 2004; Schroth et al., 2001; McGuire et al., 2002; Harris et al., 2006). In comparison, only a limited number of studies have directly measured denitrification rates from the gaseous denitrification products (Sanchez-Perez et al., 2003; Kneeshaw et al., 2007; Well and Myrold, 2002, 1999; Addy et al., 2002, 2005; Well et al., 2003; Kellogg et al., 2005; Konrad, 2007). Aside from the study of Konrad (2007), these push-pull tests have only been conducted in the uppermost groundwater.

Well et al. (2005) showed that in situ denitrification rates measured with the push-pull ${ }^{15} \mathrm{~N}$ tracer method in the saturated zone of hydromorphic soils agreed relatively well with denitrification rates measured in parallel soil samples. Konrad (2007) reported a close correlation between in situ denitrification rates and the cumulative denitrification after at least 1 year of incubation based on a small number of comparisons (five), so only a relatively small data set was used to derive transfer functions.

Since denitrification is a microbially mediated reaction, the composition, activity and amount of microbes in aquifers should directly influence the measured denitrification rates during single-well push-pull tests. It is known that steep gradients in the composition of microbial communities occur in aquifers resulting from the distribution and availability of electron donors and acceptors in aquifers (Kölbelboelke et al., 1988; Griebler and Lueders, 2009; Santoro et al., 2006). Law et al. (2010) reported substantial changes in the microbial community composition after the initiation of denitrification and the transition from denitrification to $\mathrm{Fe}(\mathrm{IIII})$ reduction within incubated aquifer material. Higher microbial activities after bio-stimulation of indigenous microorganisms by the injection of electron donors into aquifers were reported by Istok et al. (2004), Kim et al. (2005) and Kim et al. (2004). Compared with preceding push-pull tests at the same groundwater monitoring wells, the multiple injection of electron donors increased the reduction rates of $\mathrm{NO}_{3}^{-}$, pertechnetate $(\mathrm{Tc}(\mathrm{VII}))$ and $\mathrm{U}(\mathrm{VI})$ measured during subsequent push-pull tests in a shallow unconfined silty-clayey aquifer (Istok et al., 2004). Trudell et al. (1986) found increasing denitrification rates during a 12-day push-pull test in $\mathrm{NO}_{3}^{-}$-free groundwater suggesting that the microbial com- 
munity needed a certain time to adapt to the electron acceptor $\mathrm{NO}_{3}^{-}$before denitrification could proceed at a rate equivalent to the availability of reduced compounds. So far, the effect of different ambient redox conditions, i.e. the presence or absence of $\mathrm{NO}_{3}^{-}$in groundwater, on the outcome of push-pull tests has been insufficiently considered.

Overall, the performance of previous push-pull studies suggests that this approach may be suitable to deliver in situ denitrification data that reflect the reduction capacity of the aquifer, i.e. it might be used to estimate SRC without the need for collecting aquifer material. Nevertheless, individual aquifer samples should always be analysed to verify these estimates repeatedly.

To test whether ${ }^{15} \mathrm{~N}$ push-pull tests could be evaluated during the course of experiments directly in the field, a membrane inlet mass spectrometer (MIMS) was used during five push-pull tests at two monitoring wells for direct field measurements of ${ }^{15} \mathrm{~N}$-labelled denitrification products (see Supplement). The main advantages of MIMS with respect to the conventional IRMS approach is that MIMS is low-priced compared to IRMS and results can be obtained during experiments directly in the field. Sampling intervals can thus be adapted to get more precise rates. Moreover, the length of the pull phase can be limited to the duration of clearly increasing $\left(\mathrm{N}_{2}+\mathrm{N}_{2} \mathrm{O}\right)_{\text {den }}$ concentrations to save hours of labour. Finally, the relatively low cost and simple operation of the MIMS system are favourable to enable extensive application of the ${ }^{15} \mathrm{~N}$ push-pull approach to explore denitrification capacities of aquifers.

This study is the second part of a combined approach (a) to quantify exhaustibility of the denitrification capacity in aquifers, (b) to investigate controlling factors and derive predictive models during incubation experiments, and (c) to check whether the cumulative denitrification measured after 1 year of incubation $\left(D_{\text {cum }}(365)\right)$ (Eschenbach and Well, 2013) can be derived from in situ denitrification rates measured with push-pull tracer tests. Here a study on objective (c) is presented. The specific objectives of this study are (1) to measure in situ denitrification rates with push-pull ${ }^{15} \mathrm{~N}$ tracer tests at groundwater monitoring wells, (2) to develop regression models to predict $D_{\text {cum }}(365)$ as well as the stock of reduced compounds from in situ denitrification rates, and (3) to test an approach to adapt the microbial community in $\mathrm{NO}_{3}^{-}$-free aquifer zones to $\mathrm{NO}_{3}^{-}$as a newly available electron acceptor during experiments as a means of conditioning prior to subsequent push-pull ${ }^{15} \mathrm{~N}$ tracer tests. Additionally, as a fourth objective, the suitability of MIMS for online field analysis during ${ }^{15} \mathrm{~N}$ tracer tests was tested (in the Supplement).

\section{Materials and methods}

\subsection{Study sites}

In situ measurements of denitrification were conducted in the Fuhrberger Feld aquifer (FFA) and the Großenkneten aquifer (GKA). Both aquifers are located in drinking water catchment areas in the north of Germany. The FFA is situated about $30 \mathrm{~km}$ NE of the city of Hanover and the GKA about $30 \mathrm{~km} \mathrm{SW}$ of the city of Bremen. Both aquifers consist of carbonate-free Quaternary sands and the deeper parts of the GKA additionally of carbonate-free marine sands (Pliocene). The thickness of the FFA and GKA is 20 to 40 and 60 to $100 \mathrm{~m}$, respectively. Both aquifers are unconfined and contain unevenly distributed amounts of microbially available sulfides and organic carbon. Intensive agricultural land use leads to considerable $\mathrm{NO}_{3}^{-}$inputs to the groundwater of both aquifers (Böttcher et al., 1989; van Berk et al., 2005; Schuchert, 2007). Groundwater recharge is $250 \mathrm{~mm} \mathrm{yr}^{-1}$ in the FFA (Wessolek et al., 1985) and 200 to $300 \mathrm{~mm} \mathrm{yr}^{-1}$ in the GKA (Schuchert, 2007).

Evidence of an intense ongoing denitrification within the FFA is given by $\mathrm{NO}_{3}^{-}$and redox gradients (Böttcher et al., 1992) as well as excess- $\mathrm{N}_{2}$ measurements (Weymann et al., 2008). The FFA can be divided into two hydro-geochemical zones: the zone of organotrophic denitrification near the groundwater surface with organic carbon $\left(C_{\text {org }}\right)$ as an electron donor and a deeper zone of predominantly lithotrophic denitrification with pyrite as the dominant electron donor (Böttcher et al., 1991, 1992). Detailed information about the FFA is given by Strebel et al. (1992), Frind et al. (1990) and von der Heide et al. (2008). The geological structure of the GKA is described in Howar (2005) and Wirth (1990). Extended zones with oxidising and reducing conditions in the groundwater are evident in the GKA (van Berk et al., 2005) but their distribution within the aquifer is more complex than in the FFA and denitrification is known to occur in the zone of reduced groundwater (van Berk et al., 2005). Own excess- $\mathrm{N}_{2}$ measurements (Well et al., 2012) at monitoring wells prove intense denitrification within the GKA. But there are no studies on the type of denitrification in this aquifer.

\subsection{Single-well push-pull ${ }^{15} \mathrm{~N}$ tracer tests}

\subsubsection{Well types and sampling procedure}

To quantify in situ denitrification rates $\left(D_{\mathrm{r}}(\right.$ in situ $\left.)\right)$, a total of 28 single-well push-pull ${ }^{15} \mathrm{~N}$ tracer tests, afterwards referred to as push-pull tests, were performed in the FFA and GKA (Table 1) by injecting ${ }^{15} \mathrm{~N}$-labelled $\mathrm{NO}_{3}^{-}$tracer solution into groundwater monitoring wells. In the FFA, pushpull tests were conducted at multilevel wells consisting of PE tubings (4 mm ID) (Böttcher et al., 1985). Each of these tubes was connected to a filter element at the respective depth. In the GKA, two types were used: (1) conventional groundwa- 
Table 1. Overview of the conducted push-pull ${ }^{15} \mathrm{~N}$ tracer tests, the used wells and the depth range of the respective filter screens in both aquifers. Push-pull test with and without pre-conditioning were conducted at multilevel well B4.

\begin{tabular}{|c|c|c|c|c|c|c|c|c|c|c|c|}
\hline \multirow[b]{2}{*}{ Monitoring well } & \multicolumn{5}{|c|}{$\begin{array}{c}\text { Fuhrberg } \\
\text { (multilevel wells) }\end{array}$} & \multicolumn{6}{|c|}{$\begin{array}{c}\text { Großenkneten } \\
\text { (conventional monitoring and } \\
\text { multilevel wells) }\end{array}$} \\
\hline & B1 & B2 & B4 & B6 & $\begin{array}{l}\mathrm{N} 10 \\
\text { lter sc }\end{array}$ & $\begin{array}{l}\text { Gro } 326 \\
\text { en, metres }\end{array}$ & $\begin{array}{c}\text { Gro } 327 \\
\text { elow ground }\end{array}$ & surface & $\mathrm{S} 2$ & CMT1 & CMT2 \\
\hline $\begin{array}{l}\text { Non-sulfidic zone } \\
\left(\mathrm{NO}_{3}^{-} \text {-bearing zone }\right)\end{array}$ & & $\begin{array}{l}2.95-3.05 \\
4.15-4.25\end{array}$ & & $\begin{array}{l}3 \\
6\end{array}$ & & $8.0-10.0$ & & & & & $\begin{array}{r}8.15-8.40 \\
22.65-22.90\end{array}$ \\
\hline $\begin{array}{l}\text { Transition zone } \\
\left(\mathrm{NO}_{3}^{-} \text {-bearing zone) }\right.\end{array}$ & & $\begin{array}{r}7.95-8.05 \\
8.95-9.05 \\
9.95-10.05\end{array}$ & & & $\begin{array}{l}5 \\
8\end{array}$ & & & & & & \\
\hline $\begin{array}{l}\text { Sulfidic zone } \\
\left(\mathrm{NO}_{3}^{-} \text {-free zone) }\right.\end{array}$ & $\begin{array}{l}6.95-7.05 \\
7.95-8.05\end{array}$ & 13.95-14-05 & $\begin{array}{r}6.95-7.05^{*} \\
8.75-8.85^{*} \\
9.85-9.95^{*} \\
9.95-10.05^{*}\end{array}$ & & & & $35.0-39.0$ & $66.0-67.0$ & $26.0-27.0$ & $\begin{array}{l}5-29.40 \\
5-31.40 \\
5-33.60\end{array}$ & $26.65-26.90$ \\
\hline
\end{tabular}

* Push-pull tests with pre-conditioning.

ter monitoring wells (101 mm ID) with 1 to $4 \mathrm{~m}$ long filter screens and (2) multilevel wells (CMT multilevel system, Soilinst, Georgetown, Canada) consisting of PE pipes with three individual channels (13 mm ID) with $25 \mathrm{~cm}$ long filter screens at the end. Each channel ended at a different depth. To allow for a direct comparison with a previous laboratory incubation study (Eschenbach and Well, 2013), wells from the same locations and with filter screens at the same depth where the aquifer samples had been collected were selected in the FFA and GKA. In situ experiments were conducted principally as described in previous studies (Addy et al., 2002; Trudell et al., 1986; Well et al., 2003).

For sampling multilevel wells, groundwater and tracer solution were extracted with a peristaltic pump (Masterflex COLE-PARMER, Vernon Hills, USA). A submersible pump (GRUNDFOS MP1, Bjerringbro, Denmark) was used for common groundwater monitoring wells. During sampling, an outflow tube with the extracted groundwater or tracer solution was placed at the bottom of 26 or $120 \mathrm{~mL}$ serum bottles (multilevel wells and common groundwater monitoring wells, respectively). After an overflow of at least 3 times the volume of these bottles, the tubing was removed and the bottles were immediately sealed airtight with grey butyl rubber septa (ALTMANN, Holzkirchen, Germany) and aluminium crimp caps. Four replications were collected per sampling. Groundwater was sampled from the injection depth prior to each push-pull test.

\subsubsection{Push-pull tests}

A single-well push-pull test consists of the injection of a tracer solution into a monitoring well (push phase) and the extraction of the mixture of test solution and groundwater from the same well (pull phase).

\section{Push phase}

To prepare the tracer solution, 50L of groundwater was extracted from multilevel wells (FFA and GKA) or $220 \mathrm{~L}$ at common groundwater monitoring wells (GKA) for each push-pull test (Fig. 1). The groundwater was pumped to a stainless steel storage container (type BO 220 L, SPEIDEL, Ofterdingen, Germany), which was equipped with a floating lid to avoid gas exchange with the atmosphere and thus maintain the dissolved gas composition of the extracted groundwater. After extraction, a stock solution of deionised water $(100 \mathrm{~mL})$ with dissolved ${ }^{15} \mathrm{~N}$-labelled potassium nitrate $\left(\mathrm{KNO}_{3}\right.$ with 60 atom $\left.\%{ }^{15} \mathrm{~N}\right)$ and potassium bromide $(\mathrm{KBr})$ was added to attain a concentration of $10 \mathrm{mg}{ }^{15} \mathrm{~N}$-labelled $\mathrm{NO}_{3}^{-}-\mathrm{NL}^{-1}$ and $10 \mathrm{mg} \mathrm{Br}^{-} \mathrm{L}^{-1}$, respectively. The mixture of the stock solution and the extracted groundwater is hereinafter referred to as tracer solution. The tracer solution was mixed for $1 \mathrm{~h}$ with a submersible pump (Gigant, Eijkelkamp, Giesbeek, Netherlands) within the stainless steel storage container. The extracted groundwater from the $\mathrm{NO}_{3}^{-}$-bearing groundwater zone $\left(\mathrm{NO}_{3}^{-}\right.$-bearing zone) contained varying concentrations of $\mathrm{NO}_{3}^{-}$(Table 2). Consequently, the $\mathrm{NO}_{3}^{-}$in the tracer solution of these push-pull tests was a mixture of natural and ${ }^{15} \mathrm{~N}$-enriched $\mathrm{NO}_{3}^{-}$, and $\mathrm{NO}_{3}^{-}$concentrations in these tracer solutions were $>10 \mathrm{mg} \mathrm{NO}_{3}^{-}-\mathrm{NL}^{-1}$ (see discussion about influence of $\mathrm{NO}_{3}^{-}$concentrations on denitrification rates in Sect. 4.2 and in Eschenbach and Well, 2013).

During injection, the outflow of the stainless steel storage container was connected with Tygon ${ }^{\circledR}$ tubings to the selected depths of the multilevel wells. For common groundwater monitoring wells the submersible pump was connected with a pump riser pipe and an inflatable packer (packer set, UIT Umwelt- und Ingenieurtechnik GmbH, Dresden, Germany). The packer was installed within the groundwater monitoring well to prevent mixing of the injected tracer solution with the water column in the groundwater monitoring well 
Table 2. Background conditions of the groundwater from the injection depths of the push-pull ${ }^{15} \mathrm{~N}$ tracer tests.

\begin{tabular}{|c|c|c|c|c|c|c|c|c|c|}
\hline \multirow[t]{2}{*}{ Location } & \multirow{2}{*}{$\begin{array}{r}\text { Inj. depth } \\
\text { m }\end{array}$} & \multirow[t]{2}{*}{ Aquifer zone } & $\mathrm{O}_{2}$ & $\mathrm{NO}_{3}^{-}$ & $\mathrm{N}_{2} \mathrm{O}$ & $\mathrm{SO}_{4}^{2-}$ & $\mathrm{pH}$ & Redox & Cond. ${ }^{\mathrm{b}}$ \\
\hline & & & $\mathrm{mg} \mathrm{L}^{-1}$ & $\mathrm{mg} \mathrm{NL}^{-1}$ & $\mu \mathrm{gNL}^{-1}$ & $\mathrm{mg} \mathrm{S} \mathrm{L}^{-1}$ & & $\mathrm{mV}$ & $\mu \mathrm{S} \mathrm{cm}^{-1}$ \\
\hline FFA B1 & $6.95-7.05$ & sulfidic & 0.67 & $<0.25$ & n.d. & 27.64 & 6.00 & -171 & 473 \\
\hline FFA B1 & $7.95-8.05$ & sulfidic & 0.76 & $<0.25$ & n.d. & 24.73 & 6.04 & -175 & 440 \\
\hline FFA B2 & $2.95-3.05$ & non-sulfidic & 3.66 & 41.47 & 1.59 & 15.07 & 4.66 & 273 & 563 \\
\hline FFA B2 & $4.15-4.25$ & non-sulfidic & 0.96 & 27.59 & 68.31 & 36.94 & 4.83 & 209 & 564 \\
\hline FFA B2 & $7.95-8.05$ & transition zone & 0.16 & 12.58 & 0.03 & 32.52 & 4.48 & 341 & 553 \\
\hline FFA B2 & $8.95-9.05$ & transition zone & 0.13 & 7.09 & 0.05 & 38.41 & 4.65 & 367 & 488 \\
\hline FFA B2 & $9.95-10.05$ & transition zone & 0.06 & 1.0 & n.d. & 43.30 & 4.75 & 374 & 458 \\
\hline FFA B2 & $13.95-14.05$ & sulfidic & 0.40 & 0.63 & n.d. & 42.51 & 6.75 & 117 & 453 \\
\hline FFA B4 & 7.95-8.05 & sulfidic & 0.22 & $<0.25$ & 1.14 & 42.30 & 5.28 & -38 & 432 \\
\hline FFA B4 & $8.95-9.05$ & sulfidic & 0.12 & $<0.25$ & 0.70 & 51.19 & 5.43 & - & - \\
\hline FFA B6 & $2.95-3.05$ & non-sulfidic & 9.51 & 6.10 & 0.02 & 13.95 & 5.70 & 365 & 255 \\
\hline FFA B6 & $5.95-6.05$ & non-sulfidic & 1.28 & 19.55 & 10.66 & 22.45 & 5.18 & 349 & 441 \\
\hline FFA N10 & $4.95-5.05$ & transition zone & 0.12 & 13.12 & 184.8 & 59.87 & 4.61 & 341 & 660 \\
\hline FFA N10 & $7.95-8.05$ & transition zone & 0.16 & 0.4 & 1.03 & 52.03 & 5.60 & 3 & 463 \\
\hline GKA 326 & $8.0-10.0$ & non-sulfidic & 6.30 & 3.06 & 0.12 & 4.67 & 4.10 & 374 & 105 \\
\hline GKA CMT2 & $8.15-8.40$ & non-sulfidic & 6.10 & 3.14 & 0.12 & 5.06 & 4.40 & 387 & 100 \\
\hline GKA CMT2 & $22.65-22.90$ & non-sulfidic & 5.70 & 3.98 & 0.56 & 12.09 & 5.10 & 276 & 163 \\
\hline GKA CMT2 & $26.65-26.90$ & sulfidic & 0.10 & $<0.25$ & 0.01 & 18.57 & 5.40 & 30 & 221 \\
\hline GKA S2 & 26.0-27.0 & sulfidic & 0.30 & $<0.25$ & n.d. & 17.85 & 5.30 & 161 & 217 \\
\hline GKA CMT1 & $29.15-29.40$ & sulfidic & 0.20 & $<0.25$ & n.d. & 18.16 & 5.50 & -24 & 240 \\
\hline GKA CMT1 & $31.15-31.40$ & sulfidic & 0.14 & $<0.25$ & n.d. & 17.91 & 5.20 & 134 & 195 \\
\hline GKA CMT1 & $33.35-33.60$ & sulfidic & 0.20 & $<0.25$ & n.d. & 18.60 & 5.10 & 122 & 272 \\
\hline GKA 327 & $35.0-39.0$ & sulfidic & 0.10 & $<0.25$ & 0.13 & 10.85 & 5.30 & 26 & 275 \\
\hline GKA S1 & $66.0-67.0$ & non-sulfidic & 0.13 & $<0.25$ & 0.02 & 5.10 & 5.72 & -54 & 103 \\
\hline
\end{tabular}

FFA: Fuhrberger Feld aquifer; GKA: Großenkneten aquifer; ${ }^{\mathrm{a}}$ injection depth (the absolute depth can vary by a few centimetres); ${ }^{\mathrm{b}}$ conductivity; ${ }^{\mathrm{c}}$ n.d.: not detected.

(Fig. 1). The packer was inflated with air to a pressure of 1 bar above the pressure of the overlying water column. The inflated packer and the pump riser pipe remained within the groundwater monitoring well during the entire tracer test. The pump riser pipe was connected with a PVC hose $(13 \mathrm{~mm}$ ID) to the stainless steel container. For both types of monitoring wells, the tracer solution was injected gravimetrically. Injections took 30-45 min for common wells, 45-80 min for the CMT multilevel system and 150-240 min for the multilevel wells in the FFA.

\section{Pull phase}

The common groundwater monitoring wells in the GKA were constantly sampled at $12 \mathrm{~h}$ intervals. The multilevel wells in the FFA were sampled every $12 \mathrm{~h}$ during night and every 3 to $4 \mathrm{~h}$ during day to investigate more detailed temporal patterns. The multilevel wells were more suitable for this, due to their smaller dead volumes and lower extraction rates. The pull phases of the conducted tracer tests lasted a maximum of $72 \mathrm{~h}$. The first sampling was performed immediately after injection. Prior to each sampling, an amount of tracer solution sufficient to replace the dead volume of the groundwater monitoring well was extracted. In total, 4 and 30 to $60 \mathrm{~L}$ was extracted per sample from multilevel and groundwater monitoring wells, respectively. For common groundwater monitoring wells the sampling volume differed because of different lengths of filter screens and resulting different dead volumes. During extraction, groundwater temperature, dissolved oxygen, $\mathrm{pH}$ and electrical conductivity were measured with sensors (pH/Oxi 340i and $\mathrm{pH} /$ Cond 340i, WTW Wissenschaftlich-Technische Werkstätten $\mathrm{GmbH}$, Weilheim, Germany) installed in a flowthrough chamber.

\subsection{Incubation of aquifer material}

Laboratory experiments were performed to compare denitrification rates measured during laboratory anaerobic incubation $\left(D_{\mathrm{r}}(365)\right)$ with in situ denitrification rates. The incubated aquifer material originated from the same location and depths as the filter screens of the push-pull test injection points. The aquifer material was sampled and incubated as described in detail in Eschenbach and Well (2013).

Briefly, aquifer material from both aquifers was collected between 2 and $68 \mathrm{~m}$ below ground surface. The aquifer samples were incubated in transfusion bottles, in three to four replications. ${ }^{15} \mathrm{~N}$-labelled $\mathrm{KNO}_{3}$ solution was added and the 


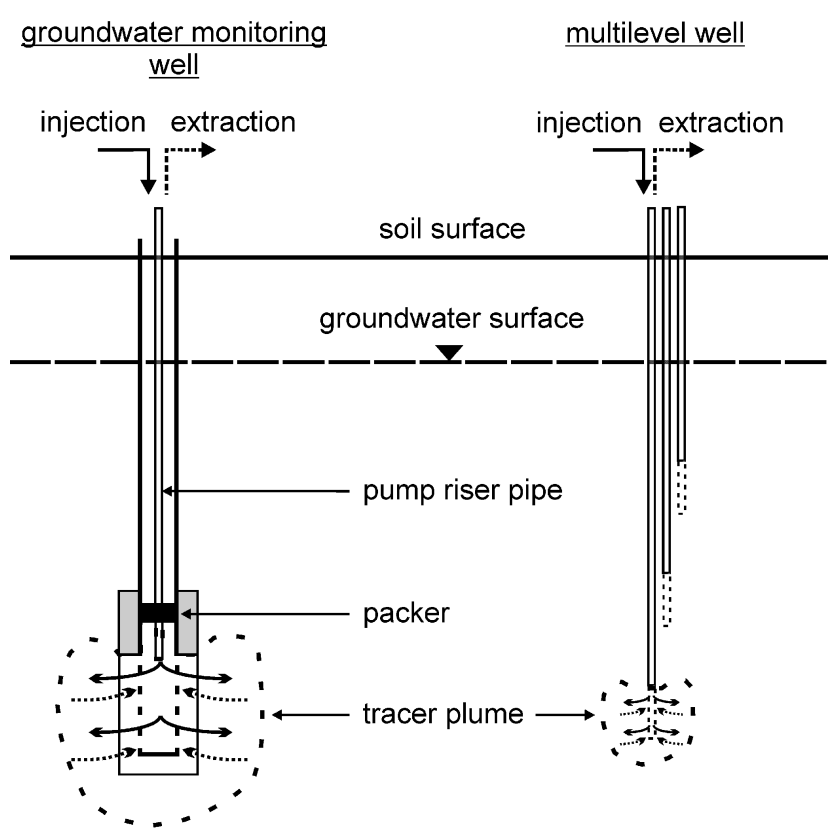

Figure 1. Schematic of push-pull ${ }^{15} \mathrm{~N}$ tracer tests at groundwater monitoring and multilevel wells.

transfusion bottles were sealed airtight. To ensure anaerobic conditions during incubation, the headspaces of the transfusion bottles were evacuated and flushed with pure $\mathrm{N}_{2}$. Afterwards, the samples were incubated for 1 year in the dark at $10^{\circ} \mathrm{C}$, which is approximately the groundwater temperature in both aquifers. The transfusion bottles were shaken manually two times a week to mix sediment and batch solution. The headspace and the supernatant batch solution in the transfusion bottles were sampled at days 1, 2, 7, 84, 168 and 365 of incubation.

\subsection{Pre-conditioning of wells in the $\mathrm{NO}_{3}^{-}$-free zone of the FFA}

To stimulate denitrification in the $\mathrm{NO}_{3}^{-}$-free zone with suspected lack of active denitrifiers (Eschenbach and Well, 2013), groundwater monitoring wells were amended by repeated injections of groundwater with added $\mathrm{NO}_{3}^{-}$of natural ${ }^{15} \mathrm{~N}$ abundance. Injections were designed to maintain elevated $\mathrm{NO}_{3}^{-}$levels in the vicinity of the filter screens during a period of several weeks. This was done to test whether in situ denitrification rates measured in these wells after pre-conditioning would reflect the average denitrification rates measured during 1 year of incubation of corresponding aquifer samples (Eschenbach and Well, 2013).

Pre-conditioning was performed at four depths in the $\mathrm{NO}_{3}^{-}$-free groundwater zone at multilevel well $\mathrm{B} 4$ in the FFA, from which two had been previously tested without preconditioning. Therefore $800 \mathrm{~L}$ of $\mathrm{NO}_{3}^{-}$-free reduced groundwater was extracted from a groundwater monitoring well, with a filter screen at 7 to $8 \mathrm{~m}$ depth below ground surface, which is located $30 \mathrm{~m}$ west of multilevel well B4, into an $800 \mathrm{~L}$ tank (IBC Tank Wassertank Container $800 \mathrm{~L}$, Barrel Trading GmbH and Co. KG, Gaildorf, Germany) using a drill pump (Wolfcraft Bohrmaschinenpumpe $8 \mathrm{~mm}$ Schaft, Wolfcraft GmbH, Kempenich, Germany). The drill pump was connected with a PVC hose (13 mm ID) to the groundwater monitoring well and to the $800 \mathrm{~L}$ tank. The extracted groundwater was supplemented with $\mathrm{KNO}_{3}$ of natural ${ }^{15} \mathrm{~N}$ abundance to a concentration of $10 \mathrm{mg} \mathrm{NO}_{3}^{-}-\mathrm{N} \mathrm{L}^{-1}$. Approximately $40 \mathrm{~L}$ of this mixture was injected weekly into each of the depths 7, 8, 9 and $10 \mathrm{~m}$ below ground surface at multilevel well B4. The injection rate was approximately $1 \mathrm{~L} \mathrm{~min}^{-1}$. For 7 and $8 \mathrm{~m}$ depth the peristaltic pump was used for injection, and for 9 and $10 \mathrm{~m}$ depth the drill pump was used; both pumps were connected with Tygon ${ }^{\circledR}$ tubings to the selected depths of the multilevel well. The first injection took place on 22 February 2011 and the last on 22 March 2011. In total, five pre-conditioning injections were conducted at the four depths. Subsequently, four push-pull tests were performed in the previously pre-conditioned injection depths as described above between 29 March and 1 April 2011.

\subsection{Analytical techniques}

\subsubsection{Isotope analysis of dissolved $\mathrm{N}_{2}$ and $\mathrm{N}_{2} \mathrm{O}$}

Water samples sampled during push-pull tests were adjusted to $25^{\circ} \mathrm{C}$ and a headspace was generated within the serum bottles by the injection of 15 or $40 \mathrm{~mL}$ of ambient air into the 26 and $115 \mathrm{~mL}$ serum bottles, respectively, replacing the same volume of sample solution. The replaced solution was directly transferred into $20 \mathrm{~mL}$ PE vials and frozen for later $\mathrm{NO}_{3}^{-}$and $\mathrm{SO}_{4}^{2-}$ analysis. After headspace generation the serum bottles were agitated for $3 \mathrm{~h}$ on a horizontal shaker at a constant temperature of $25^{\circ} \mathrm{C}$ to equilibrate the dissolved gases with the headspace gas. Finally, $13 \mathrm{~mL}$ of the headspace gas of each serum bottle was extracted with a plastic syringe and then transferred to an evacuated $12 \mathrm{~mL}$ sampling vial (Exetainer ${ }^{\circledR}$ Labco, High Wycombe, UK), giving a slight positive pressure within the sampling vial. The sampled nitrogen gases in the $12 \mathrm{~mL}$ vials were then a mixture of $\mathrm{N}_{2}$ and $\mathrm{N}_{2} \mathrm{O}$ gained from atmosphere and denitrification, respectively.

The ${ }^{15} \mathrm{~N}$ analysis of gas samples was performed via isotope ratio mass spectrometry (IRMS) at the Centre for Stable Isotope Research and Analysis in Göttingen, Germany, using a Delta $\mathrm{V}$ advantage isotope ratio mass spectrometer (Thermo Scientific, Bremen, Germany) following the method described in Well et al. (2003). Analysis included reduction of $\mathrm{N}_{2} \mathrm{O}$ to $\mathrm{N}_{2}$ prior to the mass spectrometer entrance. The sum of $\mathrm{N}_{2}$ and $\mathrm{N}_{2} \mathrm{O}$ isotopologues was thus detected as $\mathrm{N}_{2}$ in the mass spectrometer. In the following, the sum of denitrification-derived $\mathrm{N}_{2}$ and $\mathrm{N}_{2} \mathrm{O}$ is referred to as $\left(\mathrm{N}_{2}+\mathrm{N}_{2} \mathrm{O}\right)_{\text {den }}$. The ${ }^{15} \mathrm{~N}$ abundance of $\left(\mathrm{N}_{2}+\mathrm{N}_{2} \mathrm{O}\right)$ was 
derived from the measured $29 / 28$ molecular ion mass ratio. We analysed replicate samples; one was equilibrated by electrodeless discharge and the other untreated (Well et al., 1998). This allowed for calculation of $\left(\mathrm{N}_{2}+\mathrm{N}_{2} \mathrm{O}\right)_{\text {den }}$ as well as the ${ }^{15} \mathrm{~N}$ abundance in $\mathrm{NO}_{3}^{-}$undergoing denitrification. $\mathrm{N}_{2} \mathrm{O}$ was measured using a gas chromatograph (Fisons GC 8000, Milan, Italy) equipped with a split injector and an electron capture detector and a HP-Plot Q column $(50 \mathrm{~m}$ length $\times 0.32 \mathrm{~mm}$ ID; Agilent Technologies, Santa Clara, USA) kept at $38^{\circ} \mathrm{C}$. Gas analysis was completed within 2 weeks after the respective push-pull tests. The concentrations of denitrification-derived ${ }^{15} \mathrm{~N}$-labelled $\mathrm{N}_{2}$ and $\mathrm{N}_{2} \mathrm{O}$ in the gas samples were calculated as described by Well and Myrold (1999) and Well et al. (2003), respectively. The concentration of $\mathrm{N}_{2} \mathrm{O}$ in the added atmospheric air was taken into account when calculating denitrification-derived $\mathrm{N}_{2} \mathrm{O}$ in the sample. The measured molar concentrations of $\mathrm{N}_{2}$ and $\mathrm{N}_{2} \mathrm{O}$ in the headspace samples were converted into dissolved gas concentrations using gas solubilities given by Weiss (1970) and Weiss and Price (1980) and taking into account the temperature, headspace pressure and the liquidto-headspace volume ratio during equilibration of dissolved gases with the headspace gases in the serum bottles.

In addition to the standard IRMS analysis of $\left(\mathrm{N}_{2}+\mathrm{N}_{2} \mathrm{O}\right)_{\text {den }},{ }^{15} \mathrm{~N}$-labelled denitrification products were measured with a MIMS during five push-pull tracer tests directly in the field (see the Supplement).

\subsubsection{Analysis of $\mathrm{NO}_{3}^{-}, \mathrm{SO}_{4}^{2-}$ and $\mathrm{Br}^{-}$}

$\mathrm{NO}_{3}^{-}$concentrations in the water samples were determined photometrically with a continuous flow analyser (Skalar, Erkelenz, Germany). $\mathrm{SO}_{4}^{2-}$ concentrations were analysed using potentiometric back-titration of excess $\mathrm{Ba}^{2+}$ ions remaining in the solution after addition of a defined amount of $\mathrm{BaCl}_{2}$ in excess to $\mathrm{SO}_{4}^{2-} \cdot \mathrm{SO}_{4}^{2-}$ precipitated as $\mathrm{BaSO}_{4}$. The original $\mathrm{SO}_{4}^{2-}$ concentration was then analysed by potentiometric back-titration of the excess $\mathrm{Ba}^{2+}$ ions remaining in the solution using EDTA as a titrant. Possible interfering metal cations were removed from the samples prior to this analysis by cation exchange. Bromide $\left(\mathrm{Br}^{-}\right)$was analysed with an inductively coupled plasma-atomic emission spectrometer (ICP-AES; Spectro Analytical Instruments, Kleve, Germany) after stabilising the aliquot of the analysed water samples with $10 \% \mathrm{HNO}_{3}$.

\subsection{Calculation of denitrification rates}

Measured concentrations of $\left(\mathrm{N}_{2}+\mathrm{N}_{2} \mathrm{O}\right)_{\text {den }}$ were converted from $\left(\mu \mathrm{g} \mathrm{N} \mathrm{L}^{-1}\right)$ to $\left(\mu \mathrm{g} \mathrm{Ng}^{-1}\right)$ under the following assumptions: (1) the average density of the solid aquifer material is $2.65 \mathrm{~g} \mathrm{~cm}^{-3}$ and (2) the effective porosity of the aquifer material was estimated to be 0.3 from literature values for sediments of similar grain size distribution (Kollmann, 1986), with a range of uncertainty of 0.2 to 0.4 , respectively.
The concentrations of $\left(\mathrm{N}_{2}+\mathrm{N}_{2} \mathrm{O}\right)_{\text {den }}$ measured during the push-pull tests were corrected for dilution caused by dispersion, diffusion and the tortuosity of the pores. To do this the dilution factor $\left(F_{\mathrm{dil}}(t i)\right)$ (Eq. 1$)$ was derived from the concentration changes of the conservative tracer $\mathrm{Br}^{-}$during the push-pull tests as proposed by Sanches-Perez et al. (2003):

$F_{\text {dil }}(t i)=\frac{\left[\mathrm{Br}^{-}\right]_{t 0}}{\left[\mathrm{Br}^{-}\right]_{t i}}$,

where $\mathrm{Br}_{t 0}^{-}$and $\mathrm{Br}_{t i}^{-}$are the $\mathrm{Br}^{-}$concentrations of the injected tracer solution and the sampled tracer solution at sampling time $t i$, respectively. The encountered dilution factors ranged from 1 to 20 and were below 5 in 18 push-pull tests. Only during four push-pull tests were the dilution factors between 5 and 10, and only during two they were in the range of 10 to 20 . The conventional wells (GKA) showed on average higher dilution factors compared with the CMT multilevel system and the multilevel wells in the FFA. Dilution factors were near 1 for most of the push-pull tests in the FFA, i.e. the injected tracer solution interfered little with the surrounding ambient groundwater.

The corrected concentrations of $\left(\mathrm{N}_{2}+\mathrm{N}_{2} \mathrm{O}\right)_{\text {den }}$ are then obtained by multiplying the uncorrected concentrations of $\left(\mathrm{N}_{2}+\mathrm{N}_{2} \mathrm{O}\right)_{\text {den }}$ at time $t i$ with $F_{\text {dil }}(t i)$. Denitrification rates were calculated from the tangent of dilution-corrected time courses of $\left(\mathrm{N}_{2}+\mathrm{N}_{2} \mathrm{O}\right)_{\text {den }}$ concentrations at time intervals with the steepest increase during the respective push-pull test (Sanchez-Perez et al., 2003; Istok et al., 2004). This method was used because we suppose that the section of the steepest increase in measured denitrification products during a pushpull test is the best approximation of the maximal denitrification rate possible in the aquifer at the very location of the respective push-pull test. The rationale behind this is that we suppose the maximal possible denitrification rate measurable at a certain point in an aquifer is dependent on the amount of reduced compounds in the aquifer material capable of supporting denitrification. Also, the measured denitrification rate during a push-pull test is dependent on the state of the microbial community in the aquifer material at the location of the conducted push-pull test. For example, if in situ denitrification rates are measured in the zone of $\mathrm{NO}_{3}^{-}$-free groundwater, microbes might need time to express the appropriate enzymes to start to denitrify after injection of the $\mathrm{NO}_{3}^{-}$-containing tracer solution. Since it is unknown how long this adaption time might be, the highest measurable denitrification rate during a push-pull test should give an approximation for the maximal possible denitrification rate at the very point of the push-pull test (see also Sects. 4.1.2 and 4.2).

\subsection{Detection limit and precision of $\left(\mathrm{N}_{2}+\mathrm{N}_{2} \mathrm{O}\right)_{\text {den }}$ measurements}

The detection limit of ${ }^{15} \mathrm{~N}$ analysis was calculated as the minimum amount of ${ }^{15} \mathrm{~N}$-labelled $\left(\mathrm{N}_{2}+\mathrm{N}_{2} \mathrm{O}\right)_{\text {den }}$ mixed with the 
given background of headspace $\mathrm{N}_{2}$ of natural ${ }^{15} \mathrm{~N}$ abundance necessary to increase the measured ${ }^{29} \mathrm{~N}_{2} /{ }^{28} \mathrm{~N}_{2}$ ratio to fulfil the following equation:

$r_{\mathrm{sa}}-r_{\mathrm{st}} \geq 3 \times \mathrm{sd} r_{\mathrm{st}}$

where $r_{\mathrm{sa}}$ and $r_{\mathrm{st}}$ are the ${ }^{29} \mathrm{~N}_{2} /{ }^{28} \mathrm{~N}_{2}$ ratios in sample and standard, respectively, and $\operatorname{sdr}_{\mathrm{st}}$ is the standard deviation of repeated $r_{\mathrm{st}}$ measurements. The $r_{\mathrm{st}}$ values were analysed with IRMS by measuring repeated air samples. Under the experimental conditions, the detection limit for the amount of $\left(\mathrm{N}_{2}+\mathrm{N}_{2} \mathrm{O}\right)_{\text {den }}$ was 5 and $1 \mu \mathrm{g} \mathrm{NL}^{-1}$ for samples in 26 and $115 \mathrm{~mL}$ serum bottles, respectively, depending on the different ratio of liquid sample to headspace in the respective serum bottles.

The mean coefficient of variation (CV) of concentration measurements of $\left(\mathrm{N}_{2}+\mathrm{N}_{2} \mathrm{O}\right)_{\text {den }}\left(\mu \mathrm{g} \mathrm{N} \mathrm{L}^{-1}\right)$ in three replicates per sampling event during all push-pull tests was 0.18 . The conversion of concentration data from $\left(\mu \mathrm{g} \mathrm{N} \mathrm{L}^{-1}\right)$ to $\left(\mu \mathrm{g} \mathrm{kg}^{-1}\right.$ ) increased the mean CV significantly to 0.49 . (The mean $\mathrm{CV}$ after conversion to $\left(\mu \mathrm{g} \mathrm{Ng}^{-1}\right.$ ) was calculated from the three concentrations resulting from the range of effective porosity values (in the Supplement).)

\subsection{Statistical analysis and modelling}

Statistical analysis and regression modelling was conducted with WinSTAT for MS Excel version 2000.1 (R. Fitch Software, Bad Krozingen, Germany). Experimental data $(x)$ were converted into Box-Cox-transformed data $(f \mathrm{~B}-\mathrm{C}(x))$ according to Eq. (3) using different lambda coefficients $(\lambda)$ to achieve a normal-like distribution of experimental data within the different data sets.

$f^{\mathrm{B}-\mathrm{C}}(x)=\frac{\left(x^{\lambda}-1\right)}{\lambda}$

Box-Cox transformations were performed with the statistic software STATISTICA 8 (StatSoft, Tulsa, USA). Simple linear regression analysis was conducted to evaluate quantitative relations between in situ denitrification rates $\left(D_{\mathrm{r}}\right.$ (in situ)) and various sediment parameters of corresponding aquifer material measured in the laboratory (Eschenbach and Well, 2013). Normal distribution of the measured parameters within the different data sets and the residuals of linear regressions were tested with the Kolmogorov-Smirnov test; normal distribution was assumed at the $P>0.05$ level, with the null hypothesis that the tested parameter was normally distributed. The uniform distribution of residuals of regressions was checked with scatter plots of residuals vs. independent variables of the respective regression analysis. This was done to ensure homoscedasticity during regression analysis, i.e. to ensure that the least-squares method yielded best linear estimators for the modelled parameter. To use the regression functions given in the result section with own data, the experimental values have to be transformed according to
Eq. (3) with the lambda coefficients given in Table S2 in the Supplement.

Differences between partial data sets were considered significant at the $P<0.05$ level (Kruskal-Wallis test $(\mathrm{kw})$ with the null hypothesis that both partial data sets belong to the same population).

\subsection{Model sediment properties using regression functions with $D_{\mathbf{r}}$ (in situ)}

In situ denitrification rates $\left(D_{\mathrm{r}}\right.$ (in situ) ) measured during push-pull tests were used to model parameters of the investigated aquifer samples measured in the laboratory. These parameters were (1) the cumulative denitrification after 1 year of incubation ( $D_{\text {cum }}(365)$ ); (2) the SRC; and (3) several sediment parameters like water-soluble organic carbon $\left(\mathrm{C}_{\mathrm{hws}}\right)$, the fraction of $\mathrm{KMnO}_{4}$ labile organic carbon $\left(\mathrm{C}_{1}\right)$, total sulfur (total $\mathrm{S}$ ) and total organic carbon $\left(\mathrm{C}_{\text {org }}\right) . D_{\text {cum }}(365)$ is the cumulative amount of denitrification products per kilogram dry weight of incubated aquifer material at the end of 1 year of anaerobic incubation $\left(\mathrm{mg} \mathrm{N} \mathrm{kg}^{-1}\right)$. The SRC is the amount of sulfides and $\mathrm{C}_{\text {org }}$ converted into $\mathrm{N}$ equivalents $\left(\mathrm{mg} \mathrm{N} \mathrm{kg}^{-1}\right)$ according to their potential ability to reduce $\mathrm{NO}_{3}^{-}$to $\mathrm{N}_{2}$ (Eschenbach and Well, 2013). These sediment parameters and denitrification rates were analysed during a laboratory incubation study with aquifer samples from the FFA and GKA (Eschenbach and Well, 2013).

The aquifer samples were collected from drilled material obtained during construction of groundwater monitoring and multilevel wells in the FFA and GKA. The analysed aquifer samples originated from depth intervals of approximately $1 \mathrm{~m}$ above to $1 \mathrm{~m}$ below filter screens or filter elements of respective groundwater monitoring or multilevel wells used for push-pull tests (Table 1).

\section{Results}

\subsection{Grouping of push-pull test measuring points}

Push-pull tests were grouped into data subsets according to the redox state of groundwater and chemical properties of the aquifer material from the vicinity of the filter screens of groundwater monitoring wells used for the respective pushpull tests (aquifer material was collected during well construction) (see also Eschenbach and Well (2013) Sect. 3.1). These data subsets consist of data from wells with filter screens in the $\mathrm{NO}_{3}^{-}$-bearing and $\mathrm{NO}_{3}^{-}$-free groundwater zone $\left(\mathrm{NO}_{3}^{-}\right.$-bearing and $\mathrm{NO}_{3}^{-}$-free zone, respectively) and wells in the zone of non-sulfidic, sulfidic and transition zone aquifer material (Tables 1 and 2).

$0.4 \mathrm{mg} \mathrm{NO}_{3}^{-}-\mathrm{NL}^{-1}$ was the lowest measured $\mathrm{NO}_{3}^{-}$concentration above the limit of detection of $0.2 \mathrm{mg} \mathrm{NO}_{3}^{-}-\mathrm{N}$ $\mathrm{L}^{-1}$ in the various monitoring wells (Table 2). Therefore, $0.4 \mathrm{mg} \mathrm{NO}_{3}^{-}-\mathrm{NL}^{-1}$ was the lowest $\mathrm{NO}_{3}^{-}$concentration of 
groundwater to be considered nitrate-bearing in this study. Sulfidic and non-sulfidic aquifer material was distinguished using the sulfate formation capacity ( $\mathrm{SFC},\left(\mathrm{mg} \mathrm{S} \mathrm{kg}^{-1} \mathrm{yr}^{-1}\right)$ ) of incubated aquifer material from the vicinity of the respective filter screen of the used monitoring wells (Eschenbach and Well, 2013). Aquifer samples with a SFC $>1 \mathrm{mg} \mathrm{SO}_{4}^{2-}$ $\mathrm{S} \mathrm{kg}^{-1} \mathrm{yr}^{-1}$ during incubation were assigned sulfidic, and push-pull tests conducted at wells with filter screens in this zone were accordingly assigned to the sulfidic zone. The transition zone was defined as the zone within the aquifer where aquifer material still contains sulfides and groundwater still contains $\mathrm{NO}_{3}^{-}$. It follows that the $\mathrm{NO}_{3}^{-}$-bearing groundwater zone comprises the zone of non-sulfidic aquifer material and the transition zone.

\subsection{In situ denitrification rates and time courses of denitrification products}

$D_{\mathrm{r}}$ (in situ) ranged from 0.0 to $51.5 \mu \mathrm{g} \mathrm{kg}^{-1} \mathrm{~d}^{-1}$. Mean $D_{\mathrm{r}}$ (in situ) in the FFA $\left(9.1 \mu \mathrm{g} \mathrm{N} \mathrm{kg}^{-1} \mathrm{~d}^{-1}\right)$ was almost 4 to 5 times higher than in the GKA, but differences between aquifers were not significant (Figs. 2 and 3, Tables 3 and 4).

The non-sulfidic zone of both aquifers exhibited the lowest mean $D_{\mathrm{r}}$ (in situ) $\left(1.04 \mu \mathrm{g} \mathrm{N} \mathrm{kg}{ }^{-1} \mathrm{~d}^{-1}\right)$ of all partial data sets (Table 4) and statistical significant differences (kw: $P<0.05$ ) occurred with the full and all partial data sets except $D_{\mathrm{r}}$ (in situ) measured in the GKA and in the $\mathrm{NO}_{3}^{-}$-bearing zone of both aquifers. The other partial data sets exhibited no significant differences between one another. Mean $D_{\mathrm{r}}$ (in situ) of the transition zone $\left(9.32 \mu \mathrm{g} \mathrm{N} \mathrm{kg}^{-1} \mathrm{~d}^{-1}\right)$ was slightly higher than in the sulfidic zone of both aquifers.

Except for the multilevel well $\mathrm{B} 6$ at $6 \mathrm{~m}$ depth, all push-pull injection points with $\mathrm{O}_{2}$ concentrations above $1 \mathrm{mg} \mathrm{O}_{2} \mathrm{~L}^{-1}$ in the groundwater exhibited $D_{\mathrm{r}}$ (in situ) below $0.75 \mu \mathrm{g} \mathrm{N} \mathrm{kg}^{-1} \mathrm{~d}^{-1}$ (Tables 2 and 3) and aquifer material from this locations were assigned to non-sulfidic aquifer material during laboratory incubations (Eschenbach and Well, 2013).

$D_{\mathrm{r}}$ (in situ) measured after pre-conditioning of pushpull injection points at multiple well B4 (FFA) (67.83 to $152.70 \mu \mathrm{g} \mathrm{N} \mathrm{kg}^{-1} \mathrm{~d}^{-1}$ ) were 30 to 65 times higher than $D_{\mathrm{r}}$ (in situ) measured 1 year before without pre-conditioning ( 2.76 and $2.28 \mu \mathrm{g} \mathrm{N} \mathrm{kg}^{-1} \mathrm{~d}^{-1}$ ) (Table 3).

Among the total 28 push-pull tests, 24 were conducted without pre-conditioning, from which 12 were located in the $\mathrm{NO}_{3}^{-}$-bearing and 12 in the $\mathrm{NO}_{3}^{-}$-free zone of both aquifers. Among the 12 push-pull tests in the $\mathrm{NO}_{3}^{-}$-free zone all of the five FFA locations showed an exponential increase in $\left(\mathrm{N}_{2}+\mathrm{N}_{2} \mathrm{O}\right)_{\text {den }}$ during push-pull tests, whereas in the GKA this was only the case in two to three of the seven GKA locations. In contrast to this, only 2 out of 12 push-pull tests in the $\mathrm{NO}_{3}^{-}$-bearing zone of both aquifers exhibited exponential increases and these push-pull tests were located in the transition zone of multilevel well B2. The two push-pull tests at multilevel well $\mathrm{B} 4\left(\mathrm{NO}_{3}^{-}\right.$-free zone of the FFA) showed an exponential increase in $\left(\mathrm{N}_{2}+\mathrm{N}_{2} \mathrm{O}\right)_{\text {den }}$. All other push-pull tests in the $\mathrm{NO}_{3}^{-}$-bearing zone exhibited almost linear trends. After pre-conditioning at the same depths of multilevel well B4 in the $\mathrm{NO}_{3}^{-}$-free zone, the time course of denitrification products was drastically different compared to the initial tests with a much steeper and initially almost linear trend (Fig. 4).

\subsection{Relationship between $D_{\mathrm{r}}$ (in situ), $D_{\text {cum }}(365)$ and aquifer parameters}

\subsubsection{Comparison of $D_{\mathrm{r}}($ in situ $)$ and $D_{\text {cum }}(365)$}

$D_{\mathrm{r}}$ (in situ) was compared with mean denitrification rates during 365 days of laboratory incubation $\left(D_{\mathrm{r}}(365)\right)$ (Eschenbach and Well, 2013) with aquifer material collected from the locations of the monitoring wells (see Sect. 2.3). $D_{\mathrm{r}}(365)$ was obtained by dividing cumulative $\left(\mathrm{N}_{2}+\mathrm{N}_{2} \mathrm{O}\right)$ den production $\left(D_{\text {cum }}(365)\right)$ by incubation time $(365 \mathrm{~d}) . D_{\mathrm{r}}$ (in situ) was generally lower than $D_{\mathrm{r}}(365)$ (Fig. 3 and Table S1 Supplement). The means of the $D_{\mathrm{r}}$ (in situ)-to- $D_{\mathrm{r}}(365)$ ratio were calculated for the different partial data sets giving a range of 0.05 to 0.47 , with the lowest and highest ratios for the data sets of GKA and transition zone push-pull tests, respectively (Table 4). In the transition zone, $D_{\mathrm{r}}$ (in situ)-to- $D_{\mathrm{r}}(365)$ ratios were significantly higher compared to the other data sets (kw: $p<0.05$ ). Statistically, $D_{\mathrm{r}}$ (in situ) of FFA aquifer material was significantly more closely related to $D_{\mathrm{r}}(365)$ than $D_{\mathrm{r}}$ (in situ) measured in the GKA. The mean $D_{\mathrm{r}}$ (in situ)-to$D_{\mathrm{r}}(365)$ ratio from the $\mathrm{NO}_{3}^{-}$-bearing zone of both aquifers (0.23) was significantly larger than in the $\mathrm{NO}_{3}^{-}$-free zone of both aquifers (0.1) (Table 4).

$D_{\mathrm{r}}$ (in situ) after pre-conditioning (well B4, FFA) was comparable to or higher than $D_{\mathrm{r}}(365)$ with $D_{\mathrm{r}}$ (in situ)-to- $D_{\mathrm{r}}(365)$ ratios of 0.73 to 2.76 (Fig. 3 and Table 4 ). $D_{\mathrm{r}}$ (in situ) was 30 to 65 times higher compared to values obtained without preconditioning at the same wells (Fig. 5 and Table 3).

\subsubsection{Regression models to predict $D_{\text {cum }}(365)$, SRC and denitrification-relevant aquifer parameters from $D_{\mathbf{r}}$ (in situ)}

Simple linear regression analysis was applied to obtain regression models for the prediction of $D_{\text {cum }}(365)$ from $D_{\mathrm{r}}$ (in situ) for the full and partial data sets. The correlation coefficient $(R)$ and the average ratio of calculated $D_{\text {cum }}(365)$ to measured $D_{\text {cum }}(365)$ are used to evaluate the goodness of fit of the regression models.

The goodness of fit of regression models to predict $D_{\text {cum }}(365)$ by $D_{\mathrm{r}}$ (in situ) varied for the various data subsets from no fit in the sulfidic zone to a good approximation of $D_{\text {cum }}(365)$ by $D_{\mathrm{r}}$ (in situ) in the $\mathrm{NO}_{3}^{-}$-bearing zone ( $R=0.04$ and $R=0.84$, respectively, Table 5). For the full data set, the quality of the fit was modest $(R=0.62)$ resulting in a wide range of deviations between calculated and measured $D_{\text {cum }}$ (365) from -49.1 to $18.1 \mathrm{mg} \mathrm{N} \mathrm{kg}^{-1}$ in the 

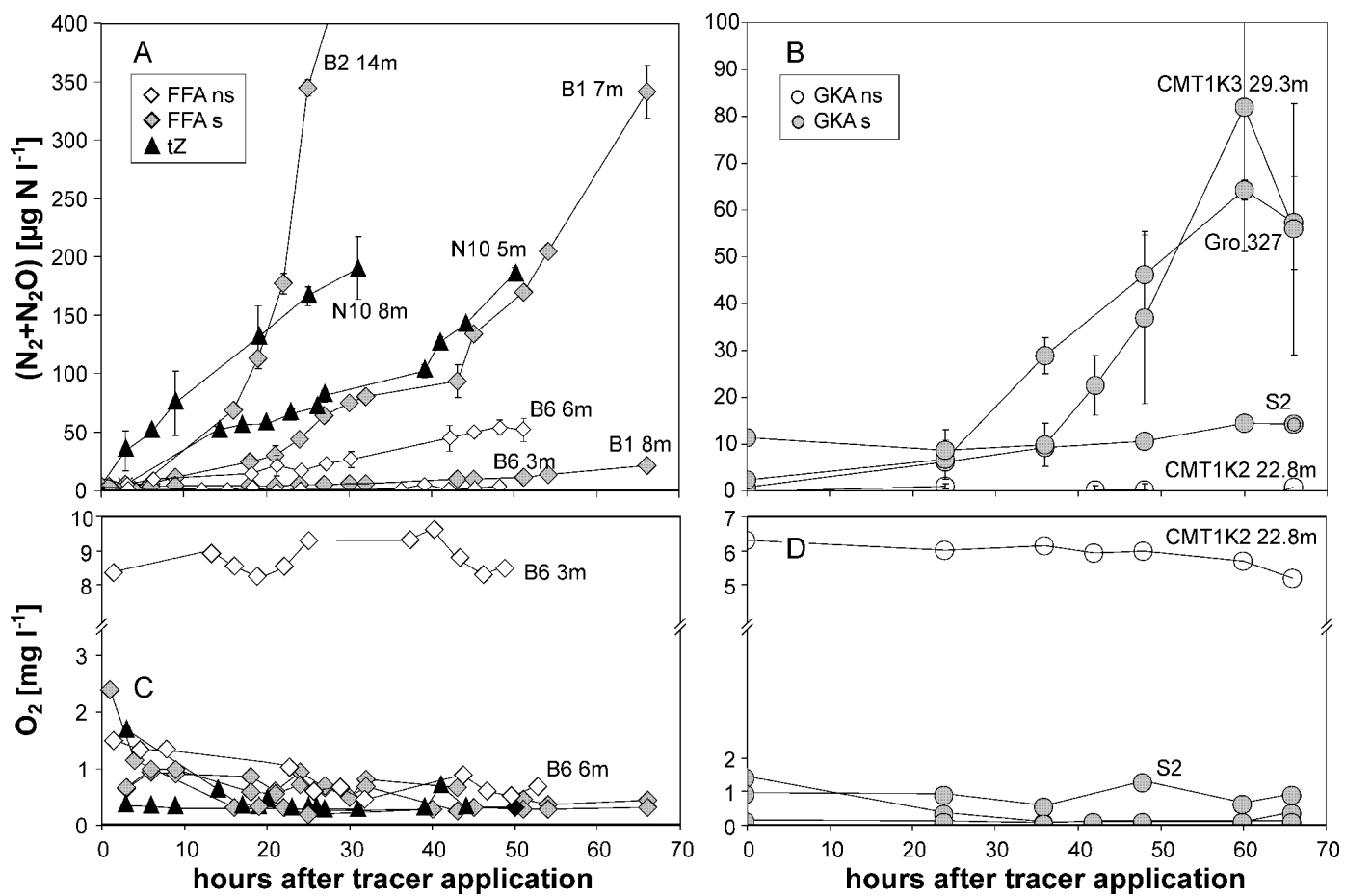

Figure 2. Time courses of denitrification-derived $\left(\mathrm{N}_{2}+\mathrm{N}_{2} \mathrm{O}\right)$ den and dissolved $\mathrm{O}_{2}$ during ${ }^{15} \mathrm{~N}$ push-pull tests in the FFA (a) and (c) and GKA (b) and (d). FFA: Fuhrberger Feld aquifer; GKA: Großenkneten aquifer; ns: non-sulfidic; s: sulfidic; tZ: transition zone aquifer material.
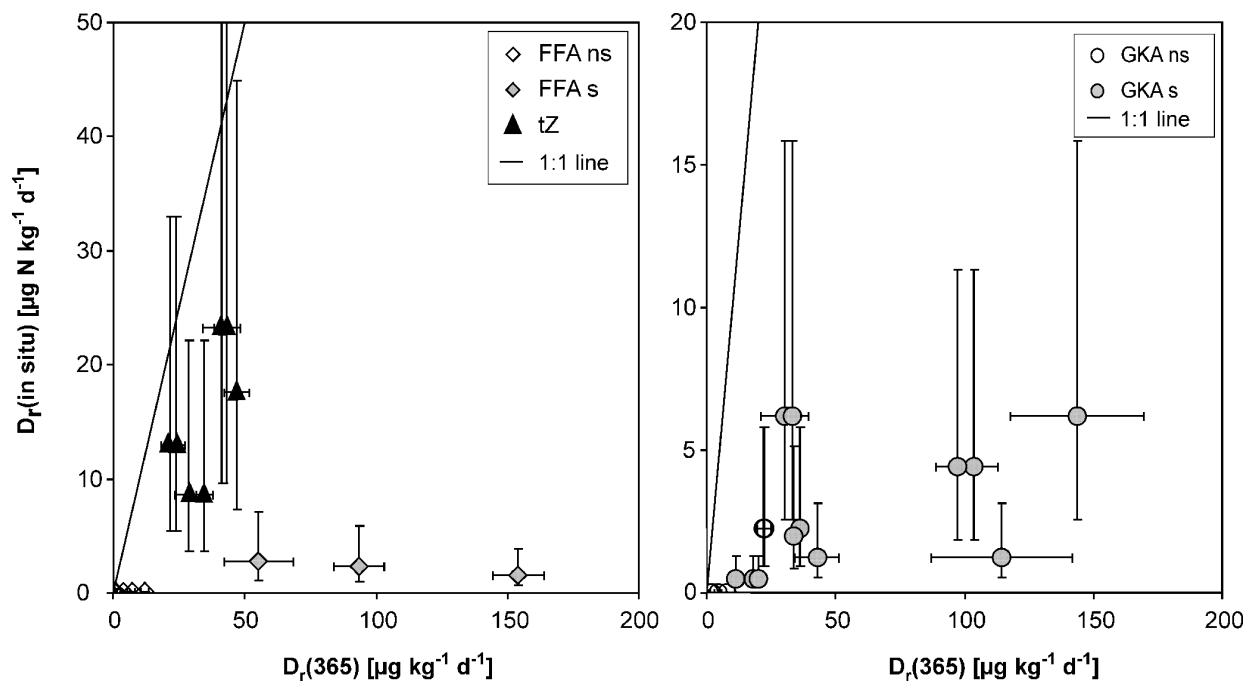

Figure 3. Relation between in situ denitrification rates determined by ${ }^{15} \mathrm{~N}$ push-pull tracer tests and average denitrification rates during 1 year of incubation (Eschenbach and Well, 2013). FFA: Fuhrberger Feld aquifer; GKA: Großenkneten aquifer; ns: non-sulfidic; s: sulfidic; tZ: transition zone aquifer material.

different data subsets. Linear relationships between $D_{\mathrm{r}}$ (in situ) and $D_{\text {cum }}(365)$ were better for GKA in comparison to FFA aquifer material. Aquifer material which was not yet in contact with $\mathrm{NO}_{3}^{-}$-bearing groundwater $\left(\mathrm{NO}_{3}^{-}\right.$-free zone and most of sulfidic zone material) exhibited $D_{\mathrm{r}}($ in situ) values which were clearly less correlated with $D_{\text {cum }}(365)$ than aquifer material which was already in contact with $\mathrm{NO}_{3}^{-}-$ bearing groundwater (non-sulfidic zone, transition zone and $\mathrm{NO}_{3}^{-}$-bearing zone) (Table 5).

The goodness of the fit of regression models to calculate the SRC from $D_{\mathrm{r}}$ (in situ) was on average slightly worse than the one of regression models to predict $D_{\text {cum }}(365)$ from $D_{\mathrm{r}}$ (in situ). As for the prediction of $D_{\text {cum }}(365)$, the best goodness of fit of regression models was obtained from the 
Table 3. In situ denitrification rates $D_{\mathrm{r}}$ (in situ) and minimum and maximum values of $D_{\mathrm{r}}$ (in situ). Minimum and maximum values correspond to the range of possible effective porosities $(0.2$ to 0.4$)$. $D_{\mathrm{r}}\left(\mathrm{in}\right.$ situ) were calculated from a regression line through the $\left(\mathrm{N}_{2}+\mathrm{N}_{2} \mathrm{O}\right)_{\text {den }}$ concentrations at time intervals with the steepest increase in $\left(\mathrm{N}_{2}+\mathrm{N}_{2} \mathrm{O}\right)_{\text {den }}$ during the respective push-pull test. Tracer tests after preconditioning are marked with *.

\begin{tabular}{|c|c|c|c|c|c|c|}
\hline \multirow[t]{2}{*}{ Location } & \multirow{2}{*}{$\begin{array}{r}\text { Injection depth }^{\mathrm{a}} \\
\mathrm{m}\end{array}$} & \multirow[t]{2}{*}{ Aquifer zone } & $D_{\mathrm{r}}$ (in situ) & $\begin{array}{r}D_{\mathrm{r}}(\text { in situ }) \\
\max \end{array}$ & $\begin{array}{r}D_{\mathrm{r}}(\text { in situ }) \\
\text { min }\end{array}$ & \multirow[t]{2}{*}{$R^{\mathrm{b}}$} \\
\hline & & & \multicolumn{2}{|c|}{$\mu \mathrm{g} \mathrm{N} \mathrm{kg}^{-1} \mathrm{~d}^{-1}$} & & \\
\hline FFA B1 & $6.95-7.05$ & sulfidic $^{\mathrm{d}}$ & 17.59 & 27.361 & 10.261 & 0.94 \\
\hline FFA B1 & $7.95-8.05$ & sulfidic $^{\mathrm{d}}$ & 1.512 & 2.352 & 0.882 & 0.92 \\
\hline FFA B2 & $2.95-3.05$ & non-sulfidic ${ }^{c}$ & 0.120 & 0.186 & 0.070 & 0.14 \\
\hline FFA B2 & $4.15-4.25$ & non-sulfidic ${ }^{c}$ & 0.065 & 0.102 & 0.038 & 0.01 \\
\hline FFA B2 & $7.95-8.05$ & transition zone $\mathrm{e}^{\mathrm{c}}$ & 0.429 & 0.667 & 0.250 & 0.95 \\
\hline FFA B2 & $8.95-9.05$ & transition zone $\mathrm{e}^{\mathrm{c}}$ & 1.415 & 2.201 & 0.825 & 0.90 \\
\hline FFA B2 & $9.95-10.05$ & transition zone $e^{\mathrm{c}}$ & 8.650 & 13.456 & 5.046 & 0.99 \\
\hline FFA B2 & $13.95-14.05$ & sulfidic $^{\mathrm{d}}$ & 51.47 & 80.078 & 30.029 & 0.82 \\
\hline FFA B4 & 7.95-8.05 & sulfidic $^{\mathrm{d}}$ & 2.755 & 4.286 & 1.607 & 0.98 \\
\hline FFA B4 & $8.95-9.05$ & sulfidic $^{\mathrm{d}}$ & 2.278 & 3.544 & 1.329 & 0.86 \\
\hline FFA B6 & $2.95-3.05$ & non-sulfidic ${ }^{c}$ & 0.057 & 0.089 & 0.033 & 0.02 \\
\hline FFA B6 & $5.95-6.05$ & non-sulfidic ${ }^{c}$ & 4.998 & 7.774 & 2.915 & 0.96 \\
\hline FFA N10 & $4.95-5.05$ & transition zone $\mathrm{e}^{\mathrm{c}}$ & 12.89 & 20.052 & 7.520 & 0.95 \\
\hline FFA N10 & $7.95-8.05$ & transition zone $e^{\mathrm{c}}$ & 23.19 & 36.074 & 13.528 & 0.99 \\
\hline FFA B4* & $6.95-7.05$ & sulfidic $^{\mathrm{d}}$ & 152.6 & 237.527 & 89.073 & 0.94 \\
\hline FFA B4* & $7.95-8.05$ & sulfidic $^{\mathrm{d}}$ & 67.83 & 105.514 & 39.568 & 0.99 \\
\hline FFA B4* & $8.95-9.05$ & sulfidic $^{\mathrm{d}}$ & 145.5 & 226.481 & 84.930 & 0.98 \\
\hline FFA B4* & $9.95-10.05$ & sulfidic $^{\mathrm{d}}$ & 150.7 & 234.530 & 87.949 & 1.00 \\
\hline GKA 326 & 8.0-10.0 & non-sulfidic $^{\mathrm{b}}$ & 0.747 & 1.162 & 0.436 & 0.96 \\
\hline GKA CMT2 & $8.15-8.40$ & non-sulfidic ${ }^{b}$ & 0.051 & 0.079 & 0.030 & 0.02 \\
\hline GKA CMT2 & $22.65-22.90$ & non-sulfidic ${ }^{\mathrm{b}}$ & 0.009 & 0.013 & 0.005 & 0.00 \\
\hline GKA CMT2 & $26.65-26.90$ & sulfidic $^{\mathrm{d}}$ & 1.233 & 1.918 & 0.719 & 0.70 \\
\hline GKA S2 & $26.0-27.0$ & sulfidic $^{\mathrm{d}}$ & 0.860 & 1.338 & 0.502 & 0.99 \\
\hline GKA CMT1 & $29.15-29.40$ & sulfidic $^{\mathrm{d}}$ & 4.427 & 6.886 & 2.582 & 0.78 \\
\hline GKA CMT1 & $31.15-31.40$ & sulfidic $^{\mathrm{d}}$ & 0.504 & 0.784 & 0.294 & 0.63 \\
\hline GKA CMT1 & $33.35-33.60$ & sulfidic $^{\mathrm{d}}$ & 2.002 & 3.114 & 1.168 & 0.77 \\
\hline GKA 327 & $35.0-39.0$ & sulfidic $^{\mathrm{d}}$ & 6.192 & 9.632 & 3.612 & 0.99 \\
\hline GKA S1 & $66.0-67.0$ & non-sulfidic ${ }^{\mathrm{d}}$ & 2.271 & 3.533 & 1.325 & 1.00 \\
\hline
\end{tabular}

FFA: Fuhrberger Feld aquifer; GKA: Großenkneten aquifer; ${ }^{\mathrm{a}}$ (the absolute depth can vary by a few $\mathrm{cm}$ ); ${ }^{\mathrm{b}}$ correlation coefficient of the regression line; ${ }^{\mathrm{c}} \mathrm{NO}_{3}^{-}$-bearing zone; ${ }^{\mathrm{d}} \mathrm{NO}_{3}^{-}$-free zone.

GKA data sets, the transition zone and the $\mathrm{NO}_{3}^{-}$-bearing zone, with coefficients of determination of $R=0.75,0.77$ and 0.50 (Table 5). Like $D_{\text {cum }}(365)$, the prediction for SRC was also best for zones of both aquifers where the aquifer material had already been in contact with $\mathrm{NO}_{3}^{-}$-bearing groundwater in situ prior to the push-pull tests. In contrast with other partial data sets, the data subset of $D_{\mathrm{r}}$ (in situ) measured in sulfidic aquifer material exhibited a clearly better goodness of fit between $D_{\mathrm{r}}$ (in situ) and SRC than between $D_{\text {cum }}(365)$ and $D_{\mathrm{r}}$ (in situ), $R=0.41$ and $R=0.04$, respectively.

As already mentioned above, pre-conditioning of multilevel well B4 strongly increased the measured $D_{\mathrm{r}}$ (in situ). Here, regressions between $D_{\mathrm{r}}$ (in situ) and $D_{\text {cum }}(365)$ and be- tween $D_{\mathrm{r}}$ (in situ) and SRC exhibited a modest goodness of fit ( $R=0.54$ and $R=0.53$, respectively) (Table 5).

Regression analysis between several denitrificationrelevant parameters of aquifer material (Eschenbach and Well, 2013) and $D_{\mathrm{r}}$ (in situ) revealed that, for some partial data sets, the linear regressions between some of these parameters and $D_{\mathrm{r}}$ (in situ) were even better than the regression between $D_{\mathrm{r}}$ (in situ) and $D_{\text {cum }}(365)$ (Table S3 Supplement in comparison to Table 5). For GKA aquifer material, $D_{\text {cum }}(365)$ was in closest linear correlation with $D_{\mathrm{r}}$ (in situ). In contrast with this, for FFA aquifer material $D_{\mathrm{r}}$ (in situ) was more closely related to $\mathrm{SO}_{4}^{2-}$ extr and $\mathrm{C}_{\mathrm{hws}}$ than to $D_{\text {cum }}(365)$ or SRC. For data subsets grouped according to the sulfate formation capacity of the incubated aquifer material, several parameters had better or at least equal linear correlation to 
Table 4. Means, standard deviation and ranges of $D_{\mathrm{r}}$ (in situ) of the data sets. Statistical significant differences $(\mathrm{kw}: P<0.05)$ between $D_{\mathrm{r}}($ in situ) values measured in the various data subsets occurred only between $D_{\mathrm{r}}$ (in situ) measured in the non-sulfidic zone and some other partial data sets.

\begin{tabular}{|c|c|c|c|c|c|c|c|}
\hline \multirow[b]{2}{*}{ Data set } & \multicolumn{4}{|c|}{$\begin{array}{c}D_{\mathrm{r}}(\text { in situ })^{\mathrm{a}} \\
\left(\mu \mathrm{kg}^{-1} \mathrm{~N} \mathrm{~d}^{-1}\right)\end{array}$} & \multicolumn{3}{|c|}{$D_{\mathrm{r}}($ in situ $) / D_{\mathrm{r}}(365)^{\mathrm{b}}$} \\
\hline & $N^{\mathrm{c}}$ & means & range & $\begin{array}{r}\text { non- } \\
\text { sulfidic }^{\mathrm{d}}\end{array}$ & $N^{\mathrm{e}}$ & means & range \\
\hline Whole data set & 24 & $6.07 \pm 11.36$ & $0.00-51.48$ & $s^{1}$ & 34 & $0.15 \pm 0.20$ & $0.00-0.60$ \\
\hline FFA & 14 & $9.10 \pm 14.20$ & $0.06-51.48$ & $\mathrm{~s}^{1}$ & 16 & $0.26 \pm 0.24$ & $0.01-0.60$ \\
\hline GKA & 10 & $1.83 \pm 2.02$ & $0.00-6.19$ & ns & 18 & $0.06 \pm 0.06$ & $0.00-0.20$ \\
\hline Non-sulfidic zone & 8 & $1.04 \pm 1.78$ & $0.00-5.00$ & - & 11 & $0.05 \pm 0.08$ & $0.00-0.23$ \\
\hline Sulfidic zone & 14 & $8.59 \pm 13.67$ & $0.43-51.48$ & $s^{2}$ & 23 & $0.20 \pm 0.22$ & $0.01-0.60$ \\
\hline Transition zone & 5 & $9.32 \pm 9.32$ & $0.43-23.19$ & $\mathrm{~s}^{1}$ & 8 & $0.47 \pm 0.14$ & $0.25-0.60$ \\
\hline $\mathrm{NO}_{3}^{-}$-bearing zone & 12 & $4.38 \pm 7.24$ & $0.00-23.19$ & ns & 17 & $0.23 \pm 0.24$ & $0.00-0.60$ \\
\hline $\mathrm{NO}_{3}^{-}$-free zone & 16 & $7.76 \pm 14.53$ & $0.50-51.48$ & $s^{1}$ & 17 & $0.10 \pm 0.10$ & $0.01-0.37$ \\
\hline B4 pre-conditioned & 4 & $128.1 \pm 43.4$ & $67.8-152.7$ & - & 4 & $1.87 \pm 0.84$ & $0.72-2.76$ \\
\hline B4 un-conditioned & 2 & $2.52 \pm 0.34$ & $2.28-2.76$ & - & 2 & $0.04 \pm 0.02$ & $0.02-0.05$ \\
\hline
\end{tabular}

${ }^{\text {a }}$ All $D_{\mathrm{r}}$ (in situ) measurements; ${ }^{\mathrm{b}}$ only $D_{\mathrm{r}}$ (in situ) measurements with corresponding incubated aquifer samples; ${ }^{\mathrm{c}}$ number of $D_{\mathrm{r}}$ (in situ) measurements; ${ }^{\mathrm{d}}$ statistical differences between non-sulfidic and other data sets (s: significant differences; ns: non-significant differences; ${ }^{1}$ differences significant at the 0.05 probability level; ${ }^{2}$ differences significant at the 0.01 probability level; ${ }^{3}$ differences significant at the 0.001 probability level); ${ }^{\mathrm{e}}$ number of comparisons between $D_{\mathrm{r}}$ (in situ) and corresponding incubated aquifer samples.
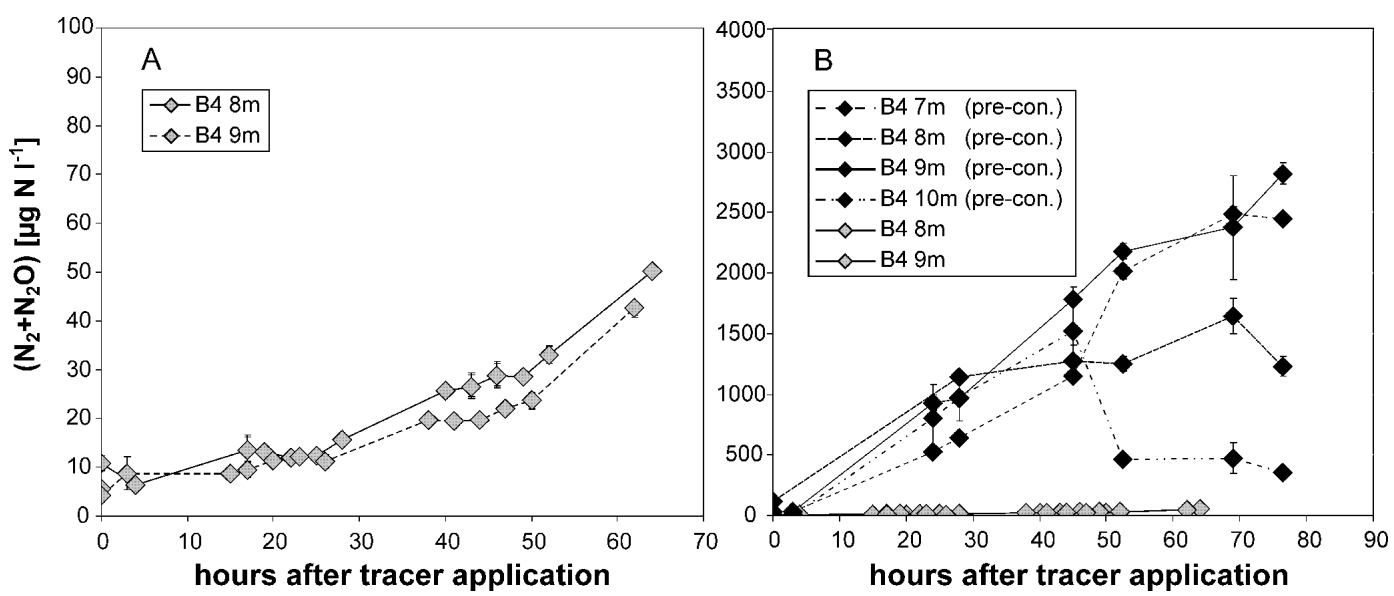

Figure 4. Time courses of $\left(\mathrm{N}_{2}+\mathrm{N}_{2} \mathrm{O}\right)_{\text {den }}$ during push-pull tests without pre-conditioning (a) (grey diamonds) and with pre-conditioning (b) (black diamonds) at multilevel well B4 in the FFA. The push-pull tests without pre-conditioning at B4 were conducted in April 2010. One year later, in April 2011, the aquifer material of the respective depths was conditioned over 5 weeks with $\mathrm{NO}_{3}^{-}$amended groundwater of natural ${ }^{15} \mathrm{~N}$ abundance prior to the ${ }^{15} \mathrm{~N}$ push-pull tests.

$D_{\mathrm{r}}$ (in situ) than $D_{\text {cum }}(365)$. These parameters were $\mathrm{C}_{\text {org }}$ and total $\mathrm{S}$ in the non-sulfidic zone, $\mathrm{SO}_{4}^{2-}$ extr and total $\mathrm{S}$ in the sulfidic zone, $\mathrm{C}_{\text {org }}$ and total $\mathrm{S}$ in the transition zone, $\mathrm{C}_{\text {org }}$ and $\mathrm{SO}_{4}^{2-}{ }_{\text {extr }}^{2-}$ in the $\mathrm{NO}_{3}^{-}$-bearing zone, and $\mathrm{SO}_{4}^{2-}$ extr and $\mathrm{C}_{l}$ in the $\mathrm{NO}_{3}^{-}$-free zone.

\section{Discussion}

\subsection{Quantifying $D_{\mathrm{r}}$ (in situ) with push-pull tests}

\subsubsection{Ranges of $D_{\mathrm{r}}$ (in situ) and comparison with previous studies}

To compare previous $D_{\mathrm{r}}$ (in situ) data with our measurements, all denitrification rates were converted to the dimension $\mu \mathrm{g} \mathrm{N} \mathrm{kg}^{-1} \mathrm{~d}^{-1}$ assuming an effective pore space of 0.3 and an average density of dry aquifer solids of $2.65 \mathrm{~g} \mathrm{~cm}^{-3}$. $D_{\mathrm{r}}$ (in situ) values measured in the FFA and GKA (Table 3) 
Table 5. Simple regressions between $D_{\mathrm{r}}$ (in situ) and $D_{\text {cum }}$ (365) and SRC from anaerobic incubations with corresponding aquifer material. $f^{\mathrm{B}-\mathrm{C}}(X)=A+B \times f^{\mathrm{B}-\mathrm{C}}\left(D_{\mathrm{r}}(\right.$ in situ $\left.)\right)$.

\begin{tabular}{|c|c|c|c|c|c|c|c|c|c|}
\hline \multirow[b]{2}{*}{ Data set } & \multirow[b]{2}{*}{$X^{\mathrm{a}}$} & \multirow[b]{2}{*}{$N^{\mathrm{b}}$} & \multirow[b]{2}{*}{$A$} & \multirow[b]{2}{*}{$B$} & \multirow[b]{2}{*}{$R^{\mathrm{c}}$} & \multicolumn{2}{|c|}{ Calculated/measured } & \multicolumn{2}{|c|}{$\begin{array}{c}\text { Deviation } \\
\left(\mathrm{mg} \mathrm{N} \mathrm{kg}^{-1} \mathrm{yr}^{-1}\right)\end{array}$} \\
\hline & & & & & & mean & range & mean & range \\
\hline Whole data set & $D_{\text {cum }}(365)$ & 34 & 2.878 & 0.603 & 0.62 & $2.29 \pm 4.19$ & $0.16-22.96$ & $-3.07 \pm 14.67$ & $-47.2-12.8$ \\
\hline Whole data set & SRC & 34 & 6.123 & 0.152 & 0.40 & $1.51 \pm 1.31$ & $0.12-5.19$ & $-671.2 \pm 2091$ & $-7734-1379$ \\
\hline FFA & $D_{\text {cum }}(365)$ & 16 & 2.640 & 0.578 & 0.52 & $2.83 \pm 4.90$ & $0.13-19.18$ & $-3.08 \pm 14.71$ & $-49.1-7.0$ \\
\hline FFA & SRC & 16 & 3.772 & 0.006 & 0.07 & $1.22 \pm 0.82$ & $0.11-2.92$ & $-377.8 \pm 1375$ & $-5317-413.7$ \\
\hline GKA & $D_{\text {cum }}(365)$ & 18 & 3.046 & 0.818 & 0.82 & $1.34 \pm 0.92$ & $0.26-3.85$ & $-2.25 \pm 12.28$ & $-30.8-5.5$ \\
\hline GKA & $\mathrm{SRC}$ & 18 & 8.024 & 0.613 & 0.75 & $1.43 \pm 1.23$ & $0.178-4.47$ & $-617.0 \pm 2179$ & $-5780-2390$ \\
\hline Non-sulfidic & $D_{\text {cum }}(365)$ & 11 & 1.050 & 0.156 & 0.40 & $2.25 \pm 3.20$ & $0.26-10.65$ & $-0.10 \pm 2.41$ & $-5.2-1.8$ \\
\hline Non-sulfidic & SRC & 11 & 8407 & 752.8 & 0.43 & $1.50 \pm 0.84$ & $0.46-3.19$ & $31.54 \pm 240.7$ & $-553-272.6$ \\
\hline Sulfidic & $D_{\text {cum }}(365)$ & 23 & 4.185 & -0.033 & 0.04 & $1.33 \pm 0.90$ & $0.30-4.19$ & $-3.32 \pm 15.13$ & $-39.4-13.1$ \\
\hline Sulfidic & SRC & 23 & 21.40 & -1.372 & 0.41 & $0.30 \pm 0.18$ & $0.03-0.61$ & $-1823 \pm 2313$ & $-8564-144$ \\
\hline Transition zone & $D_{\text {cum }}(365)$ & 8 & 1.109 & 0.581 & 0.53 & $1.03 \pm 0.26$ & $0.74-1.43$ & $-0.36 \pm 2.84$ & $-4.5-3.3$ \\
\hline Transition zone & SRC & 8 & 5.349 & -0.602 & 0.77 & $1.05 \pm 0.41$ & $0.58-1.92$ & $-50.11 \pm 340.6$ & $-518.7-561$ \\
\hline $\mathrm{NO}_{3}^{-}$-bearing & $D_{\text {cum }}(365)$ & 17 & 2.132 & 0.454 & 0.84 & $2.21 \pm 3.76$ & $0.13-15.17$ & $-0.67 \pm 2.52$ & $-6.3-2.7$ \\
\hline $\mathrm{NO}_{3}^{-}$-bearing & $\mathrm{SRC}$ & 17 & 193.3 & 16.32 & 0.55 & $1.36 \pm 0.75$ & $0.41-2.76$ & $-19.35 \pm 365.2$ & $-929-462.6$ \\
\hline $\mathrm{NO}_{3}^{-}$-free & $D_{\text {cum }}(365)$ & 17 & 7.774 & 2.036 & 0.36 & $1.47 \pm 0.88$ & $0.31-3.00$ & $-1.69 \pm 16.23$ & $-38.7-18.1$ \\
\hline $\mathrm{NO}_{3}^{-}$-free & $\mathrm{SRC}$ & 17 & 77.61 & 8.421 & 0.21 & $1.78 \pm 1.46$ & $0.27-4.47$ & $-485.4 \pm 2494$ & $-6077-2095$ \\
\hline Pre-conditioned ${ }^{1}$ & $D_{\text {cum }}(365)$ & 4 & 14.402 & 0.099 & 0.54 & $1.06 \pm 0.35$ & $0.62-1.47$ & $0.12 \pm 9.49 .79$ & $-12.95-9.41$ \\
\hline Pre-conditioned ${ }^{1}$ & SRC & 4 & 319.5 & 4.895 & 0.53 & $1.12 \pm 0.52$ & $0.51-1.77$ & $5.5 \pm 462$ & $-638.0-464$ \\
\hline
\end{tabular}

${ }^{1}$ Experimental data of pre-conditioned push-pull tracer tests were not Box-Cox-transformed before regression analysis because of the small number of data pairs. For these data pairs the following equation applies: $X=A+B \times D_{\mathrm{r}}$ (in situ). ${ }^{\mathrm{a}}$ Independent sediment parameter; ${ }^{\mathrm{b}}$ number of samples; ${ }^{\mathrm{c}}$ correlation coefficient.

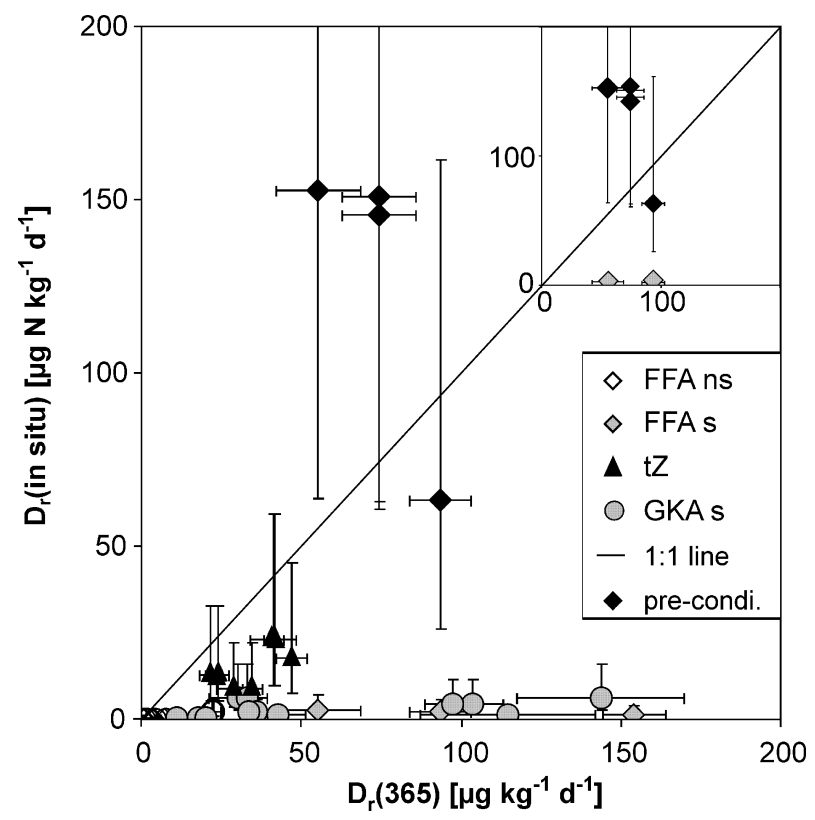

Figure 5. $D_{\mathrm{r}}$ (in situ) after 5 weeks of pre-conditioning of aquifer material (black diamonds) in comparison to $D_{\mathrm{r}}$ (in situ) without preconditioning. The small graph shows the difference between $D_{\mathrm{r}}$ (in situ) after pre-conditioning and unconditioned $D_{\mathrm{r}}$ (in situ) at multilevel well B4 in the FFA. are comparable with $D_{\mathrm{r}}$ (in situ) $\left(2.3-27.1 \mu \mathrm{g} \mathrm{N} \mathrm{kg}-1 \mathrm{~d}^{-1}\right)$ measured by Konrad (2007) in two Pleistocene sandy aquifers in northern Germany (aquifers of Thülsfelde and Sulingen, about $40 \mathrm{~km}$ west and $30 \mathrm{~km}$ south of the city of Bremen, respectively). Also, $D_{\mathrm{r}}$ (in situ) reported by Addy et al. $(2002,2005)$ shows a similar range of denitrification rates, with $2.1-121.2$ and $0.5-87.9 \mu \mathrm{g} \mathrm{N} \mathrm{kg}^{-1} \mathrm{~d}^{-1}$, respectively. Those values were measured in two riparian sites and a site with marsh sediments in Rhode Island, USA. Somewhat larger spans of $D_{\mathrm{r}}$ (in situ) were reported by Well et al. (2003) for water-saturated mineral sub-soils from various locations in northern Germany and by Konrad (2007) for the sandy to silty aquifer of Wehnsen (about $30 \mathrm{~km}$ southeast of the FFA) with $D_{\mathrm{r}}$ (in situ) from 0 to 300 and 45 to $339 \mu \mathrm{g} \mathrm{N} \mathrm{kg}{ }^{-1} \mathrm{~d}^{-1}$, respectively. These larger spans also cover the full range of $D_{\mathrm{r}}$ (in situ) values measured at multilevel well B4 in the FFA after pre-conditioning (Table 3). Sanches-Perez (2003) measured $D_{\mathrm{r}}$ (in situ) from 22.1 to $7646.4 \mu \mathrm{g} \mathrm{N} \mathrm{kg}{ }^{-1} \mathrm{~d}^{-1}$ with the acetylene inhibition method in two shallow sandy aquifers in France and Spain. Overall, there is a wide range of reported $D_{\mathrm{r}}$ (in situ) in aquifers.

Denitrification rates can also be derived from the analysis of groundwater samples from monitoring-well transects along hypothesised groundwater flow paths. Therefore, Tesoriero and Puckett (2011) selected 12 study sites with monitoring-well transects within the US. The study areas represented a wide range of sedimentary environ- 
ments and climatic conditions. Tesoriero and Puckett (2011) generalised the determined denitrification rates broadly into three categories: low rates $\left(<0.02 \mu \mathrm{g} \mathrm{Ng} \mathrm{k}^{-1} \mathrm{~d}^{-1}\right)$, medium rates $\left(0.02-0.06 \mu \mathrm{g} \mathrm{N} \mathrm{kg}^{-1} \mathrm{~d}^{-1}\right)$ and high rates $\left(>0.6 \mu \mathrm{g} \mathrm{kg}^{-1} \mathrm{~d}^{-1}\right.$ ). Low rates were found in areas with elevated $\mathrm{O}_{2}$ concentrations in the groundwater, medium rates in the presence of low $\mathrm{O}_{2}$ concentrations and high denitrification rates when changes in the lithology resulted in a sharp increase in the supply of electron donors (Tesoriero and Puckett, 2011, p. 13). Overall, the denitrification rates obtained from theses monitoring-well transects are below the mean $D_{\mathrm{r}}$ (in situ) of the various data subsets in this study (Table 4). For example, the mean $D_{\mathrm{r}}$ (in situ) of nonsulfidic aquifer material was $1 \mu \mathrm{g} \mathrm{kg}^{-1} \mathrm{~d}^{-1}$ (Table 4) and thus even higher than the high denitrification rates reported by Tesoriero and Puckett (2011). The $\mathrm{O}_{2}$ concentrations in the ambient groundwater at these push-pull locations were mostly clearly above $1 \mathrm{mg} \mathrm{L}^{-1}$, which is near the reported apparent threshold for the onset of denitrification in aquifers (Green et al., 2008, 2010; McMahon et al., 2004; Tesoriero and Puckett, 2011) (see Sect. 4.3). Mean $D_{\mathrm{r}}$ (in situ) values of data subsets of push-pull test at locations with low $\mathrm{O}_{2}$ concentrations (transition zone and $\mathrm{NO}_{3}^{-}$-free zone) (Table 2) were 9 and $8 \mu \mathrm{g} \mathrm{kg} \mathrm{k}^{-1} \mathrm{~d}^{-1}$, respectively, and thus a factor of 10 higher than the high rates reported by Tesoriero and Puckett (2011).

Green et al. (2010) showed that groundwater mixing due to advection and mechanical dispersion can strongly influence the derived apparent denitrification rates along flow paths in such a way that these transport processes tend "to create the appearance of lower reaction rates and fractionation parameters when measured at larger scales and longer flow paths" (Green et al., 2010, p. 12). Green et al. (2010) showed that mixing effects increase with the mean travel distances of groundwater and they conclude that "effects of transport and scale should be considered when comparing reaction rates in different aquifer systems, or when comparing reaction rates in different parts of the same system".

In contrast, Korom et al. (2005) reported a clearly higher zero-order denitrification rate of $35.6 \mu \mathrm{g} \mathrm{N} \mathrm{kg}^{-1} \mathrm{~d}^{-1}$ measured in an aquifer mesocosm; this rate is comparable with the highest $D_{\mathrm{r}}$ (in situ) measured in this study (Table 2). Korom et al. (2012) argued that, in contrast with monitoringwell transects, such transport-dependent mixing processes would not influence denitrification rates measured by aquifer mesocosms, since advection and mechanical dispersion are negligible. The influence of advection and mechanical dispersion on the measured apparent denitrification rates from push-pull tests should be higher compared to in situ mesocosms. However, during push-pull tests, mixing processes by advection and mechanical dispersion should be significantly lower in comparison to monitoring-well transects, since the flow path of the injected tracer solution in the aquifer is in a decimetre or, at most, metre range during a push-pull test, which is very short compared to flow paths of hundreds of metres or several kilometres in the case of monitoring-well transects. (Additionally, the mixing of the injected tracer solution with ambient groundwater was taken into account by the addition of $\mathrm{Br}^{-}$as conservative tracer to the tracer solution (see Sect. 2.6) to minimise the influence of mixing effects.)

The observed differences in denitrification rates measured in this study with denitrification rates derived from monitoring-well transects (Tesoriero and Puckett, 2011) might thus be attributed to effects of transport along long flow paths. We think that these effects should also be considered when denitrification rates are compared that have been derived with different methods.

\subsubsection{Temporal and spatial variability of in situ denitrification rates}

In addition to possible systematic differences between different methods with respect to the derived denitrification rates, it has to be taken into account that $D_{\mathrm{r}}$ (in situ) can show a considerable temporal variability during push-pull tests itself. This was evident during the 12-day-long pull phase of a push-pull test conducted by Trudell et al. (1986) in the $\mathrm{O}_{2}$ and $\mathrm{NO}_{3}^{-}$-free groundwater zone of a shallow sandy aquifer in southwestern Ontario Canada, where $D_{\mathrm{r}}$ (in situ) increased from 30.3 to $504.6 \mu \mathrm{g} \mathrm{N} \mathrm{kg}^{-1} \mathrm{~d}^{-1}$ (Trudell et al., 1986).

In this study most of the push-pull tests in the $\mathrm{NO}_{3}^{-}$-free zone showed an exponential increase in $\left(\mathrm{N}_{2}+\mathrm{N}_{2} \mathrm{O}\right)_{\text {den }}$ with time, i.e. increasing denitrification rates, which is comparable to the results of Trudell et al. (1986). Periods of an exponential increase in dilution-corrected denitrification products during tracer tests were also previously reported (Eschenbach and Well, 2011; Konrad, 2007). In the study of Konrad (2007), 5 out of 13 push-pull tests showed an exponential increase in dilution-corrected denitrification products. Four of these five push-pull tests were located in the $\mathrm{NO}_{3}^{-}$-free groundwater zone. Conversely, push-pull tests in the $\mathrm{NO}_{3}^{-}$-free zone (consisting of the data subsets of nonsulfidic aquifer material and the transition zone) showed approximately constant denitrification rates during the pushpull tests. The non-sulfidic aquifer material exhibited very low denitrification rates during the push-pull tests, presumably because the aquifer material was depleted in reduced compounds capable of supporting denitrification (Table S1 in the Supplement and Eschenbach and Well (2013) Sect. 4.2) and dissolved $\mathrm{O}_{2}$ in groundwater inhibited $\mathrm{NO}_{3}^{-}$reduction. Dissolved $\mathrm{O}_{2}$ concentrations in the ambient groundwater and therefore also in the injected test solutions were $>1 \mathrm{mg} \mathrm{O}_{2} \mathrm{~L}^{-1}$ at six out of eight injection points in the nonsulfidic zone of both aquifers (Table 2), which is near or above the apparent threshold for the onset of denitrification in aquifers (see Sect. 4.3 below), whereas $\mathrm{O}_{2}$ concentrations in the transition zone were far below this threshold. In relation to the amount of reduced compounds of transition zone 
aquifer material (Table $\mathrm{S} 1$ in the Supplement and Fig. 2 in Eschenbach and Well, 2013), which was almost as low as the one of non-sulfidic aquifer material, the denitrification rates measured in situ were comparatively high (Table 3). Despite the clearly lower SRC content in situ denitrification rates in the transition zone were on average higher than in the $\mathrm{NO}_{3}^{-}$-free zone (Table 3 ). We suspect that the clearly different activity of denitrification in relation to the SRC in the transition zone compared to the $\mathrm{NO}_{3}^{-}$-free zone is because the microbial community in the $\mathrm{NO}_{3}^{-}$-free zone is not ready to denitrify since it needs time to adapt to $\mathrm{NO}_{3}^{-}$as a possible electron acceptor.

Therefore, it is concluded that the exponential increase in denitrification products observed during push-pull tests in our study and previous studies can probably be attributed to growth and stimulation of denitrifiers by the injection of $\mathrm{NO}_{3}^{-}$into aquifer zones that have previously not been in contact with $\mathrm{NO}_{3}^{-}$. Trudell et al. (1986) found an increase in denitrifying bacteria species during the 12-day-long tracer test which was accompanied by a 17-fold increase in measured denitrification rates. Several other investigations have shown increasing microbial activity after bio-stimulation of aquifer sediments by the injection of electron donors into monitoring wells (Istok et al., 2004; Kim et al., 2004, 2005). Istok et al. (2004) reported that the viable biomass on solid samplers installed in monitoring wells more than doubled compared with samplers installed in monitoring wells without electron donor addition.

To establish an active denitrifying microbial community in the strict anaerobic zone of an aquifer, we injected $\mathrm{NO}_{3}^{-}$as the newly available electron acceptor in the $\mathrm{NO}_{3}^{-}$-free zone at multilevel well B4 in the FFA. To our knowledge, this study is the first to have used pre-conditioning of aquifer material prior to a push-pull ${ }^{15} \mathrm{~N}$ tracer test by the injection of only $\mathrm{NO}_{3}^{-}$. Pre-conditioning at multilevel well B4 (see Sect. 2.4) resulted in a 30- to 65-fold increase in measured in situ denitrification rates compared with push-pull tests without preconditioning at the same depths of multilevel well B4 (Table 3 and Fig. 5). It can be concluded that pre-conditioning in the $\mathrm{NO}_{3}^{-}$-free zone of the FFA led to growth of the community of active denitrifiers in the aquifer material in the vicinity of the respective injection points. The increase in $D_{\mathrm{r}}$ (in situ) due to pre-conditioning might be a combined effect from the increase in active denitrifiers and a higher denitrification rate per microbial cell due to synthesis of enzymes for denitrification. Pre-conditioning does not only lead to higher denitrification rates; the time course of $\left(\mathrm{N}_{2}+\mathrm{N}_{2} \mathrm{O}\right)_{\text {den }}$ also did not show a period of a distinct exponential increase compared with prior measurements without pre-conditioning (Fig. 4). This might show that denitrifiers in the tested aquifer material after pre-conditioning were ready to denitrify and that there was a stable denitrifying community (see also Sect. 4.2). Preconditioning also improved the comparability of in situ and laboratory denitrification rates compared to in situ denitrification rates measured with normal push-pull tests (Fig. 5).

All in all the measured denitrification rates during 1 year of incubation $\left(D_{\mathrm{r}}(365)\right)$ were on average higher in comparison to denitrification rates derived with normal push pull tests $\left(D_{\mathrm{r}}\right.$ (in situ)). This may have resulted from several factors, including the stimulation of denitrification in the lab due to disturbance of aquifer material, establishment of strictly anaerobic conditions, and the adaptation of the microbial community over time. The ratio between $D_{\mathrm{r}}$ (in situ) and $D_{\mathrm{r}}(365)$ was highly variable within the data set. Interestingly, it was lowest in the non-sulfidic and $\mathrm{NO}_{3}^{-}$-free zones of both aquifers (Table 4). In the case of non-sulfidic aquifer material, dissolved $\mathrm{O}_{2}$ (Table 2) might have inhibited $\mathrm{NO}_{3}^{-}$reduction. $D_{\mathrm{r}}(365)$ of non-sulfidic aquifer material measured during anaerobic incubation in the laboratory (Eschenbach and Well, 2013) can therefore be seen as a potential activity which is only partly effective under in situ conditions due to a low reduction rate of dissolved $\mathrm{O}_{2}$ in groundwater. This is also reflected by the low $D_{\mathrm{r}}$ (in situ)-to- $D_{\mathrm{r}}(365)$ ratio in the non-sulfidic wells (Table 4 ). The mean $D_{\mathrm{r}}$ (in situ)-to- $D_{\mathrm{r}}(365)$ ratio in the $\mathrm{NO}_{3}^{-}$-bearing zone was twice as high compared to the $\mathrm{NO}_{3}^{-}$-free zone (Table 4 and Fig. 3). This probably reflects the need for microbial adaptation to $\mathrm{NO}_{3}^{-}$in the $\mathrm{NO}_{3}^{-}$-free zone discussed in the previous section. Mean $D_{\mathrm{r}}$ (in situ) and the ratio of $D_{\mathrm{r}}$ (in situ) to $D_{\mathrm{r}}(365)$ of 0.47 were highest in the transition zone, showing that, in the transition zone, $D_{\mathrm{r}}$ (in situ) and $D_{\mathrm{r}}(365)$ were in closer agreement compared with other zones. During the push-pull tests in the transition zone, the ambient concentration of dissolved $\mathrm{O}_{2}$ was always below $0.13 \mathrm{mg} \mathrm{L}^{-1}$ and $\mathrm{NO}_{3}^{-}$was always detectable in the ambient groundwater at the five injection points in the transition zone (Table 2). Denitrification was therefore presumably not inhibited by dissolved $\mathrm{O}_{2}$ and the microbial population had already adapted to $\mathrm{NO}_{3}^{-}$as an available electron acceptor. Hence, denitrifying conditions during push-pull tests and during laboratory incubation were similar, resulting in closer agreement in denitrification rates.

\subsection{Interpretation of observed time courses of produced $\left(\mathbf{N}_{2}+\mathbf{N}_{2} \mathbf{O}\right)$ den}

Figure 6 sums up our interpretation of the results from pushpull tests in the $\mathrm{NO}_{3}^{-}$-free zone. Immediately after the injection of the ${ }^{15} \mathrm{~N}$ tracer in the $\mathrm{NO}_{3}^{-}$-free zone of both aquifers there seems to follow a time interval with little to no production of ${ }^{15} \mathrm{~N}$-labelled $\left(\mathrm{N}_{2}+\mathrm{N}_{2} \mathrm{O}\right)_{\text {den }}$ (i.e. lag phase) (compare with Figs. 2 and 4). During this time, denitrifiers might still have to synthesise enzymes for denitrification and are not yet ready to denitrify.

After the lag phase follows a phase of exponential increase in $\left(\mathrm{N}_{2}+\mathrm{N}_{2} \mathrm{O}\right)_{\text {den }}$ during which the amount of active denitrifiers and or their activity might adapt to the newly available electron acceptor $\mathrm{NO}_{3}^{-}$. The growth of denitrifiers might depend on the microbially available SRC, i.e. on the surface 


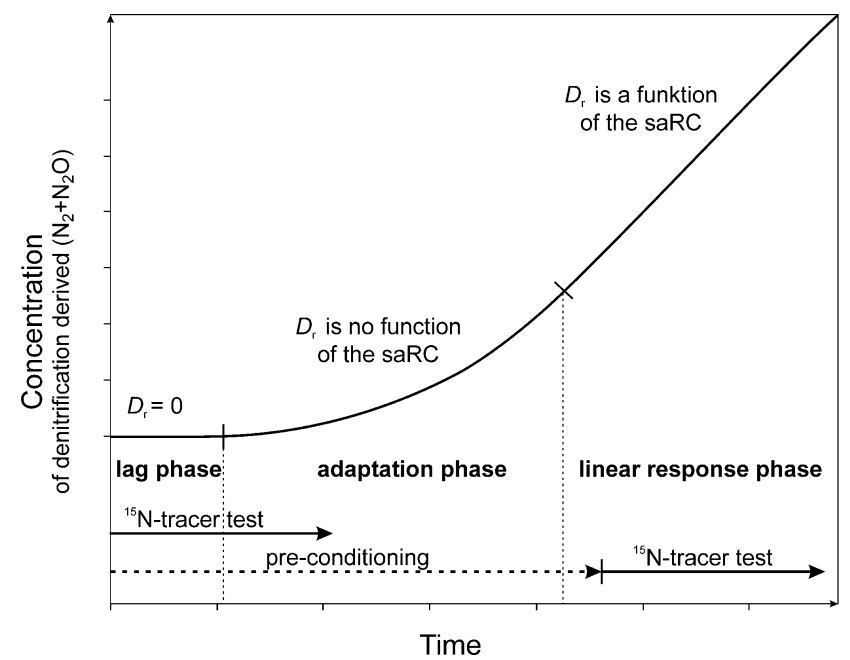

Figure 6. Schematic time courses of denitrification during pushpull tests in the $\mathrm{NO}_{3}^{-}$-free groundwater zone. $\left(D_{\mathrm{r}}\right.$ : measured in situ denitrification rates; saRC: surface area of reduced compounds present in the investigated aquifer.)

area of reduced compounds (saRC) present in the aquifer material. If the denitrifying community is adapted to $\mathrm{NO}_{3}^{-}$and had colonised the saRC, denitrification rates should be relatively constant. Hence a zero-order reaction model should fit the measured data during the relatively short duration of a push-pull test (Fig. 6, linear response phase). It is suspected that these conditions apply to the $\mathrm{NO}_{3}^{-}$-bearing zone but not to the $\mathrm{NO}_{3}^{-}$-free zone. After pre-conditioning at multilevel well $\mathrm{B} 4,\left(\mathrm{~N}_{2}+\mathrm{N}_{2} \mathrm{O}\right)_{\text {den }}$ was initially high and there was no subsequent exponential increase, while the opposite was the case during previous tests at the same well without pre-conditioning (Fig. 4). This probably reflects the more constant activity of denitrifiers during the push-pull tests after pre-conditioning (Fig. 6, linear response phase). Similar adaptation effects have been reported previously, where biostimulation by injecting electron donors like ethanol, glucose, propane or fumarate resulted in constant activity, thus allowing the use of zero-order reaction models to derive reduction rates during push-pull tests (Istok et al., 2004; Kim et al., 2004, 2005). This supports our interpretation that preconditioning leads to a kind of equilibrium between the denitrifying community, the injected $\mathrm{NO}_{3}^{-}$and the saRC present in the aquifer material, ultimately resulting in relatively constant reaction rates while $\mathrm{NO}_{3}^{-}$is not limiting (Fig. 6, linear response phase). In our experiments, the latter condition was fulfilled, because $\mathrm{NO}_{3}^{-}$concentrations during the pull phase were always clearly above $1.0 \mathrm{mg} \mathrm{NO}_{3}^{-}-\mathrm{NL}^{-1}$, which is assumed to be the threshold of $\mathrm{NO}_{3}^{-}$concentrations limiting denitrification rates reported by Wall et al. (2005).

From the dynamics of microbial adaptation outlined above it follows that pre-conditioning prior to push-pull tests in the zone of $\mathrm{NO}_{3}^{-}$-free groundwater is needed to allow for the SRC to be estimated from in situ denitrification rates.

\subsection{Predicting $D_{\text {cum }}(365)$ and SRC of aquifer sediments from $D_{\mathbf{r}}$ (in situ)}

The main objective of this study is to predict the cumulative denitrification measured during 1 year of laboratory incubation of aquifer samples $\left(D_{\text {cum }}(365)\right)$ and the SRC from in situ denitrification rates $\left(D_{\mathrm{r}}(\mathrm{in}\right.$ situ $)$ ). In comparison to costly drilling of aquifer material and laboratory measurement of $D_{\text {cum }}(365)$ and SRC, $D_{\mathrm{r}}$ (in situ) can be measured with relatively low-cost push-pull tests at existing groundwater monitoring wells, which would thus allow spatial mapping of denitrification activity within aquifers.

There are only scarce data comparing the SRC or longerterm denitrification rates (e.g. $\left.D_{\mathrm{r}}(365)\right)$ with $D_{\mathrm{r}}($ in situ)). Well et al. (2003) showed for denitrification in the saturated zone of hydromorphic soils that laboratory-derived denitrification rates after $24 \mathrm{~h}$ of anaerobic incubation were in good agreement with in situ denitrification rates, but the study was limited to near-surface groundwater. Konrad (2007) tested this approach in deeper aquifer zones with a small data set of pairs of $D_{\mathrm{r}}$ (in situ) vs. $D_{\text {cum }}$ (four push-pull ${ }^{15} \mathrm{~N}$ tracer tests and incubations of corresponding aquifer material) and found that both quantities were related (Spearman rank correlation coefficients of $R \geq 0.8$ ).

In this study, transfer functions were developed to predict $D_{\text {cum }}(365)$ from $D_{\mathrm{r}}$ (in situ) measurements with a larger data set in different redox zones typically present in aquifers. Moreover, pre-conditioning was evaluated through addition of $\mathrm{NO}_{3}^{-}$to aquifer material and the subsequent measurement of in situ denitrification rates.

Only a modest goodness of fit $(R=0.62)$ was found using linear regression between $D_{\mathrm{r}}$ (in situ) and $D_{\text {cum }}(365)$ for the full data set (Table 5). Without Box-Cox transformations of input data the correlation coefficient was even lower $(R=$ $0.1)$. This shows that it was necessary to transform the input data to approach normal distribution and homoscedasticity for regression analysis. Otherwise the ordinary least-squares method did not find the best or efficient linear estimators for regression coefficients.

Like in the previous laboratory study (Eschenbach and Well, 2013), grouping of $D_{\mathrm{r}}$ (in situ) measuring points by locality or according to hydro-geochemical zones increased the predictive power of $D_{\mathrm{r}}$ (in situ) with respect to the measured $D_{\text {cum }}(365)$ and SRC of aquifer material for some partial data sets. Altogether, $D_{\mathrm{r}}$ (in situ) was the best predictor for $D_{\text {cum }}$ (365) and SRC of the partial data set of GKA aquifer material, with correlation coefficients of 0.82 and 0.75 , respectively. For the FFA the predictive power of $D_{\mathrm{r}}$ (in situ) for $D_{\text {cum }}(365)$ and SRC was significantly lower compared to the GKA (Table 5). This finding mirrors results of laboratory incubations with FFA and GKA material reported by Eschenbach and Well (2013) (Table 4 of the cited study), in which 
initial denitrification rates $\left(D_{\mathrm{r}}(7)\right)$ of GKA material were a better predictor of $D_{\text {cum }}(365)$ than in the case of FFA material. In contrast with the GKA aquifer samples, the SRC of the FFA samples was not predictable by $D_{\mathrm{r}}$ (in situ). One reason might be a different microbial availability of organic carbon $\left(\mathrm{C}_{\text {org }}\right)$, which is one major constituent of SRC in both aquifers (Eschenbach and Well, 2013). The ratio of $\mathrm{KMnO}_{4}$ labile organic carbon $\left(\mathrm{C}_{1}\right)$ to $\mathrm{C}_{\text {org }}$ was almost twice as high in the GKA material compared to the FFA material (Eschenbach and Well, 2013), suggesting that the proportion of $\mathrm{C}_{\text {org }}$ available for microbes is higher in the GKA aquifer material and that a significant proportion of $\mathrm{C}_{\text {org }}$ is unavailable for denitrification in the FFA.

Grouping of aquifer material according to hydrogeochemical zones or sediment parameters resulted in better regressions between $D_{\mathrm{r}}$ (in situ) and $D_{\text {cum }}(365)$ and SRC for partial data sets where $\mathrm{NO}_{3}^{-}$is still present in the groundwater, i.e. in the transition and $\mathrm{NO}_{3}^{-}$-bearing zone (Table 5). Konrad (2007) reported similar relationship between $D_{\mathrm{r}}$ (in situ) and $D_{\text {cum }}$ (365) under comparable conditions. Relatively weak fits were obtained for data sets with push-pull measuring points located completely or mostly in the zone of $\mathrm{NO}_{3}^{-}$free groundwater $\left(\mathrm{NO}_{3}^{-}\right.$-free zone and sulfidic aquifer material, respectively) and in the non-sulfidic zone (Table 5). For the $\mathrm{NO}_{3}^{-}$-free zone this is attributed to a missing adaptation of the microbial community to $\mathrm{NO}_{3}^{-}$as an electron acceptor as discussed above. In the study of Trudell et al. (1986) it took at least 8 days until measured denitrification rates stopped increasing during the push-pull test. In our study, such long pull periods were not possible because of comparatively higher groundwater velocities in both aquifers. At some injection points in the FFA, the tracer plume had already moved away with groundwater within $35 \mathrm{~h}$ of the injection.

The goodness of fit in the modelling of $D_{\text {cum }}(365)$ and SRC using linear regression functions was highly variable among partial data sets. The mean ratios of calculated $D_{\text {cum }}(365)$ to measured $D_{\text {cum }}(365)$ and calculated SRC and measured SRC were best for the transition zone with ratios near 1 . We suppose the reasons for this might be (1) that residual reduced compounds that could support denitrification were still present in the aquifer material, (2) the $\mathrm{O}_{2}$ concentrations in the ambient groundwater (Table 2) were far below the reported apparent threshold of $<40-60 \mu \mathrm{mol} \mathrm{L}^{-1}$ $\left(\approx 1.5-2.3 \mathrm{mg} \mathrm{O}_{2} \mathrm{~L}^{-1}\right)$ for the onset of denitrification in aquifers (Green et al., 2008, 2010; McMahon et al., 2004; Tesoriero and Puckett, 2011) (see also Sect. 4.1 in Eschenbach and Well, 2013), and (3) $\mathrm{NO}_{3}^{-}$was present in the ambient groundwater of the transition zone. Therefore we expect that the microbial community was already adapted to $\mathrm{NO}_{3}^{-}$, i.e. ready to denitrify, and denitrification was not inhibited by dissolved $\mathrm{O}_{2}$. Conversely, in the non-sulfidic zone, higher $\mathrm{O}_{2}$ concentrations might have inhibited denitrification and this might have been more limiting for $D_{\mathrm{r}}$ (in situ) than the lim- ited content of reduced compounds. This might explain the poor fit between calculated and measured values (Table 5) in the non-sulfidic zone. In the $\mathrm{NO}_{3}^{-}$-free zone the groundwater was almost $\mathrm{O}_{2}$-free and, in comparison to the other zones, the aquifer material had a larger SRC (Table S1 in the Supplement). Nonetheless, the correlation coefficients between $D_{\mathrm{r}}\left(\right.$ in situ) and $D_{\text {cum }}(365)$ and $D_{\mathrm{r}}(\mathrm{in}$ situ) and the SRC were very low and the developed regression functions underestimated $D_{\text {cum }}(365)$ and SRC of deeper aquifer samples with high values of $D_{\text {cum }}(365)$ and SRC to a large extent (Table 5). We suppose the reason for this is the lack of adaptation of the microbial community to $\mathrm{NO}_{3}^{-}$, as already discussed above.

Pre-conditioning at multilevel well B4 led to a clearly better fit of $D_{\mathrm{r}}$ (in situ) and $D_{\mathrm{r}}(365)$ (Table 4). This indicates that pre-conditioning should increase the predictability of $D_{\text {cum }}(365)$ and probably also SRC from $D$ r(in situ) measurements in the $\mathrm{NO}_{3}^{-}$-free zone.

\section{Conclusions}

The possibility to predict the capacity of aquifer zones to remove $\mathrm{NO}_{3}^{-}$inputs over extended time periods based on in situ measurement of denitrification rates was evaluated in two Pleistocene aquifers in northern Germany. This was done by comparison of $D_{\mathrm{r}}$ (in situ) with denitrification parameters determined in aquifer material samples, i.e. the stock of reduced compounds (SRC) and the cumulative denitrification measured during 1 year of incubation in the laboratory $\left(D_{\text {cum }}(365)\right)$.

Prediction of $D_{\text {cum }}(365)$ and SRC from $D_{\mathrm{r}}$ (in situ) for data sets containing data from both aquifers was only satisfactory in the aquifer zones where $\mathrm{NO}_{3}^{-}$was present. This type of in situ test might thus be suitable for mapping $D_{\text {cum }}(365)$ and $\mathrm{SRC}$ in $\mathrm{NO}_{3}^{-}$-bearing zones of Pleistocene sandy aquifers using existing monitoring wells. It is thus a promising and low-cost method to estimate $D_{\text {cum }}(365)$ of aquifer material from aquifer zones where $\mathrm{NO}_{3}^{-}$is still present in the groundwater. Our results also indicate that the push-pull technique (without pre-conditioning) is not suited for deriving the SRC or $D_{\text {cum }}(365)$ of aquifer samples from in situ denitrification rates under conditions where the groundwater is nitrate-free.

Moreover, future routine applications of this approach could be facilitated by online field analysis using membrane inlet mass spectrometry (MIMS), which we demonstrated to be feasible and precise. Still, the correction for dilution of the injected tracer solution with ambient groundwater is necessary when using MIMS in the field (see Sect. 2.6 and the Supplement).

In the $\mathrm{NO}_{3}^{-}$-free aquifer zone, increasing denitrification rates were observed during the conducted push-pull tests, which were interpreted as the result of adaptation processes of the denitrifying communities following $\mathrm{NO}_{3}^{-}$injections. Also $D_{\mathrm{r}}$ (in situ) without pre-conditioning was generally lower than average denitrification rates after 1 year of incu- 
bation $\left(D_{\mathrm{r}}(365)\right)$ in the laboratory. This was especially the case for $D_{\mathrm{r}}$ (in situ) measurements in the $\mathrm{NO}_{3}^{-}$-free groundwater zone. In this study it was demonstrated that the microbial community in the $\mathrm{NO}_{3}^{-}$-free zone just below the $\mathrm{NO}_{3}^{-}$bearing zone can be adapted to denitrification by amending wells with $\mathrm{NO}_{3}^{-}$injections for an extended period. In situ denitrification rates measured after this pre-conditioning reflected the $D_{\text {cum }}(365)$ and SRC more satisfactorily. From these findings it is assumed that microbial adaptation after $\mathrm{NO}_{3}^{-}$injection confounded the relationship between reactive compounds present in the tested aquifer material and $D_{\mathrm{r}}$ (in situ) measured during push-pull tests, which resulted in poor prediction of $D_{\text {cum }}(365)$ and SRC from $D_{\mathrm{r}}$ (in situ). Therefore we assume that pre-conditioning is a prerequisite for the measurement of in situ denitrification rates using push-pull tracer tests in the $\mathrm{NO}_{3}^{-}$-free groundwater zone. Further research is needed to check whether this microbial adaptation would also work in deeper layers far below the $\mathrm{NO}_{3}^{-}$-bearing zone.

\section{The Supplement related to this article is available online at doi:10.5194/bg-12-2327-2015-supplement.}

\begin{abstract}
Acknowledgements. This research was made possible by financial support from the Deutsche Bundesstiftung Umwelt (DBU). The authors would like to thank I. Ostermeyer and K. Schmidt for their assistance in the laboratory; L. Szwec and R. Langel (Centre for Stable Isotope Research, University of Göttingen) for stable isotope analyses; R. Hoppe and W. Raue (enercity, Hannover) and W. Duijnisveld (Federal Institute for Geosciences and Natural Resources (Hannover)) for support during pre-conditioning; and M. Dietze and R. Liedl (Institut für Grundwasserwirtschaft (Dresden)) for technical support with the push-pull tests. We would also like to thank Jeremy Smith for suggestions that helped to improve the language. The two anonymous reviewers and the associate editor of this journal are gratefully acknowledged for their valuable comments on a previous version of this manuscript.
\end{abstract}

Edited by: M. Dai

\section{References}

Addy, K., Kellogg, D. Q., Gold, A. J., Groffman, P. M., Ferendo, G., and Sawyer, C.: In situ push-pull method to determine ground water denitrification in riparian zones, J. Environ. Qual., 31, 1017-1024, 2002.

Addy, K., Gold, A., Nowicki, B., McKenna, J., Stolt, M., and Groffman, P.: Denitrification capacity in a subterranean estuary below a Rhode Island fringing salt marsh, Estuaries, 28, 896-908, 2005.

Böttcher, J., Strebel, O., and Duijnisveld, W. H. M.: Vertikale Stoffkonzentrationsprofile im Grundwasser eines LockergesteinsAquifers und deren Interpretation (Beispiel Fuhrberger Feld), Z. dt. Geol. Ges., 136, 543-552, 1985.
Böttcher, J., Strebel, O., and Duijnisveld, W. H. M.: Kinetik und Modellierung gekoppelter Stoffumsetzungen im Grundwasser eines Lockergesteins-Aquifers., Geol. Jahrb. Reihe C, 51, 3-40, 1989.

Böttcher, J., Strebel, O., and Duijnisveld, W. H. M.: Reply (to a comment of Scott F. Korom), Water Resour. Res., 27, 32753278, 1991.

Böttcher, J., Strebel, O., and Kölle, W.: Redox conditions and microbial sulfur reactions in the Fuhrberger Feld sandy aquifer., Progress in Hydrogeochemistry, 219-226, 1992.

Burgin, A. J. and Hamilton, S. K.: Have we overemphasized the role of denitrification in aquatic ecosystems? A review of nitrate removal pathways, Front. Ecol. Environ., 5, 89-96, doi:10.1890/1540-9295(2007)5[89:hwotro]2.0.co;2, 2007.

Eschenbach, W. and Well, R.: Online measurement of denitrification rates in aquifer samples by an approach coupling an automated sampling and calibration unit to a membrane inlet mass spectrometry system, Rapid Commun. Mass Spectrom., 25, 1993-2006, doi:10.1002/rcm.5066, 2011.

Eschenbach, W. and Well, R.: Predicting the denitrification capacity of sandy aquifers from shorter-term incubation experiments and sediment properties, Biogeosciences, 10, 1013-1035, doi:10.5194/bg-10-1013-2013, 2013.

Frind, E. O., Duynisveld, W. H. M., Strebel, O., and Böttcher, J.: Modeling of multicomponent transport with microbial transformation in groundwater - The Fuhrberg case, Water Resour. Res., 26, 1707-1719, 1990.

Green, C. T., Puckett, L. J., Bohlke, J. K., Bekins, B. A., Phillips, S. P., Kauffman, L. J., Denver, J. M., and Johnson, H. M.: Limited occurrence of denitrification in four shallow aquifers in agricultural areas of the United States, J. Environ. Qual., 37, 994-1009, doi:10.2134/jeq2006.0419, 2008.

Green, C. T., Bohlke, J. K., Bekins, B. A., and Phillips, S. P.: Mixing effects on apparent reaction rates and isotope fractionation during denitrification in a heterogeneous aquifer, Water Resour. Res., 46, W08525, doi:10.1029/2009wr008903, 2010.

Griebler, C. and Lueders, T.: Microbial biodiversity in groundwater ecosystems, Freshw. Biol., 54, 649-677, doi:10.1111/j.13652427.2008.02013.x, 2009.

Groffman, P. M., Altabet, M. A., Bohlke, J. K., Butterbach-Bahl, K., David, M. B., Firestone, M. K., Giblin, A. E., Kana, T. M., Nielsen, L. P., and Voytek, M. A.: Methods for measuring denitrification: Diverse approaches to a difficult problem, Ecol. Appl., 16, 2091-2122, 2006.

Harris, S. H., Istok, J. D., and Suflita, J. M.: Changes in organic matter biodegradability influencing sulfate reduction in an aquifer contaminated by landfill leachate, Microb. Ecol., 51, 535-542, 10.1007/s00248-006-9043-y, 2006.

Hiscock, K. M., Lloyd, J. W., and Lerner, D. N.: Review of natural and artificial denitrification of groundwater, Water Res., 25, 1099-1111, 1991.

Howar, M.: Geologische 3D-Untergrundmodellierung im Bereich Großenkneten/Ahlhorn., unpubl. Expertise: INSIGHT. Geologische Softwaresysteme GmbH, Köln, Germany, 11 S., 2005.

Istok, J. D., Humphrey, M. D., Schroth, M. H., Hyman, M. R., and Oreilly, K. T.: Single-well, "push-pull" test for in situ determination of microbial activities, Ground Water, 35, 619-631, 1997.

Istok, J. D., Senko, J. M., Krumholz, L. R., Watson, D., Bogle, M. A., Peacock, A., Chang, Y. J., and White, D. C.: In situ bioreduc- 
tion of technetium and uranium in a nitrate-contaminated aquifer, Environ. Sci. Technol., 38, 468-475, doi:10.1021/es034639p, 2004.

Kellogg, D. Q., Gold, A. J., Groffman, P. M., Addy, K., Stolt, M. H., and Blazejewski, G.: In situ ground water denitrification in stratified, permeable soils underlying riparian wetlands, J. Environ. Qual., 34, 524-533, 2005.

Kim, Y., Istok, J. D., and Semprini, L.: Push-pull tests for assessing in situ aerobic cometabolism, Ground Water, 42, 329-337, doi:10.1111/j.1745-6584.2004.tb02681.x, 2004.

Kim, Y., Kim, J. H., Son, B. H., and Oa, S. W.: A single well pushpull test method for in situ determination of denitrification rates in a nitrate-contaminated groundwater aquifer, Water Sci. Technol., 52, 77-86, 2005.

Kneeshaw, T. A., McGuire, J. T., Smith, E. W., and Cozzarelli, I. M.: Evaluation of sulfate reduction at experimentally induced mixing interfaces using small-scale push-pull tests in an aquifer-wetland system, Appl. Geochem., 22, 2618-2629, doi:10.1016/j.apgeochem.2007.06.006, 2007.

Kölbelboelke, J., Anders, E. M., and Nehrkorn, A.: Microbial communities in the saturated groundwater environment .2. Diversity of bacterial communities in a Pleistocene sand aquifer and their invitro activeties, Microb. Ecol., 16, 31-48, doi:10.1007/bf02097403, 1988.

Kölle, W., Strebel, O., and Böttcher, J.: Formation of sulfate by microbial denitrification in a reducing aquifer, Water Supply, 3, 3540, 1985.

Kollmann, W.: Die Bestimmung des durchflußwirksamen Porenvolumens von Sedimenten und seine Bedeutung für den Grundwasserschutz, Mitt. österr. geol. Ges., 79, 14, 1986.

Konrad, C.: Methoden zur Bestimmung des Umsatzes von Stickstoff für drei pleistozäne Grundwasserleiter Norddeutschlands, PhD Thesis, Univ. of Tech. Dresden, Dresden, Germany, 161 pp., 2007

Korom, S. F.: Natural denitrification in the saturated zone-a review, Water Resour. Res., 28, 1657-1668, 1992.

Korom, S. F., Schlag, A. J., Schuh, W. M., and Schlag, A. K.: In situ mesocosms: denitrification in the Elk Valley aquifer, Ground Water Monit. R., 25, 79-89, 2005.

Korom, S. F., Schuh, W. M., Tesfay, T., and Spencer, E. J.: Aquifer denitrification and in situ mesocosms: modeling electron donor contributions and measuring rates, J. Hydrol., 432-433, 112126, doi:10.1016/j.jhydrol.2012.02.023, 2012.

Law, G. T. W., Geissler, A., Boothman, C., Burke, I. T., Livens, F. R., Lloyd, J. R., and Morris, K.: Role of Nitrate in Conditioning Aquifer Sediments for Technetium Bioreduction, Environ. Sci. Technol., 44, 150-155, doi:10.1021/es9010866, 2010.

McGuire, J. T., Long, D. T., Klug, M. J., Haack, S. K., and Hyndman, D. W.: Evaluating behavior of oxygen, nitrate, and sulfate during recharge and quantifying reduction rates in a contaminated aquifer, Environ. Sci. Technol., 36, 2693-2700, doi:10.1021/es015615q, 2002.

McMahon, P. B., Bohlke, J. K., and Christenson, S. C.: Geochemistry, radiocarbon ages, and paleorecharge conditions along a transect in the Central High Plains aquifer, Southwestern Kansas, USA, Appl. Geochem., 19, 1655-1686, doi:10.1016/j.apgeochem.2004.05.003, 2004.

Rivett, M. O., Buss, S. R., Morgan, P., Smith, J. W. N., and Bemment, C. D.: Nitrate attenuation in groundwater: A review of bio- geochemical controlling processes, Water Res., 42, 4215-4232, doi:10.1016/j.watres.2008.07.020, 2008.

Sánchez-Pérez, J. M., Bouey, C., Sauvage, S., Teissier, S., Antiguedad, I., and Vervier, P.: A standardised method for measuring in situ denitrification in shallow aquifers: numerical validation and measurements in riparian wetlands, Hydrol. Earth Syst. Sci., 7, 87-96, doi:10.5194/hess-7-87-2003, 2003.

Santoro, A. E., Boehm, A. B., and Francis, C. A.: Denitrifier community composition along a nitrate and salinity gradient in a coastal aquifer, Appl. Environ. Microbiol., 72, 2102-2109, doi:10.1128/aem.72.3.2102-2109.2006, 2006.

Schroth, M. H., Kleikemper, J., Bolliger, C., Bernasconi, S. M., and Zeyer, J.: In situ assessment of microbial sulfate reduction in a petroleum-contaminated aquifer using push-pull tests and stable sulfur isotope analyses, J. Contam. Hydrol., 51, 179-195, 2001.

Schuchert, A.: Zielflächenidentifikation für Grundwasserschutzmaßnahmen. Eine GIS-Datenanalyse im Wasserschutzgebiet Großenkneten, Landkreis Oldenburg, Diploma thesis, Institute for Geography, University of Bremen, Germany, 2007.

Seitzinger, S., Harrison, J. A., Bohlke, J. K., Bouwman, A. F., Lowrance, R., Peterson, B., Tobias, C., and Van Drecht, G.: Denitrification across landscapes and waterscapes: A synthesis, Ecol. Appl., 16, 2064-2090, 2006.

Senko, J. M., Istok, J. D., Suflita, J. M., and Krumholz, L. R.: In-situ evidence for uranium immobilization and remobilization, Environ. Sci. Technol., 36, 1491-1496, doi:10.1021/es011240x, 2002.

Strebel, O., Böttcher, J., and Duijnisveld, W. H. M.: Identifizierung und Quantifizierung von Stoffumsetzungen in einem Sand-Aquifer (Beispiel Fuhrberger Feld), DVGW Schriftenreihe Wasser, 73, 55-73, 1992.

Tesoriero, A. J. and Puckett, L. J.: $\mathrm{O}_{2}$ reduction and denitrification rates in shallow aquifers, Water Resour. Res., 47, W12522, doi:10.1029/2011wr010471, 2011.

Trudell, M. R., Gillham, R. W., and Cherry, J. A.: An insitu study of the occurence and rate of denitrification in a shallow unconfined sand aquifer, J. Hydrol., 83, 251-268, 1986.

van Berk, W., Kübeck, C., Steding, T., van Straaten, L., and Wilde, S.: Vorstudie zur Hydrogeologie im Wassergewinnungsgebiet Großenkneten., unpubl. Expertise: Leonardo Van Straaten GeoInfometric GmbH, Hildesheim, Germany, 55 pp., 2005.

Vitousek, P. M., Aber, J. D., Howarth, R. W., Likens, G. E., Matson, P. A., Schindler, D. W., Schlesinger, W. H., and Tilman, G. D.: Human alteration of the global nitrogen cycle: Sources and consequences, Ecol. Appl., 7, 737-750, 1997.

von der Heide, C., Bottcher, J., Deurer, M., Weymann, D., Well, R., and Duijnisveld, W. H. M.: Spatial variability of $\mathrm{N}_{2} \mathrm{O}$ concentrations and of denitrification-related factors in the surficial groundwater of a catchment in Northern Germany, J. Hydrol., 360, 230-241, doi:10.1016/j.jhydrol.2008.07.034, 2008.

Wall, L. G., Tank, J. L., Royer, T. V., and Bernot, M. J.: Spatial and temporal variability in sediment denitrification within an agriculturally influenced reservoir, Biogeochemistry, 76, 85111, doi:10.1007/s10533-005-2199-6, 2005.

Weiss, R. F.: Solubility of nitrogen, oxygen and argon in water and seawater, Deep-Sea Research, 17, 721-735, 1970.

Weiss, R. F. and Price, B. A.: Nitrous-oxide solubility in water and seawater, Mar. Chem., 8, 347-359, 1980. 
Well, R. and Myrold, D. D.: Laboratory evaluation of a new method for in situ measurement of denitrification in water-saturated soils, Soil Biol. Biochem., 31, 1109-1119, 1999.

Well, R. and Myrold, D. D.: A proposed method for measuring subsoil denitrification in situ, Soil Sci. Soc. Am. J., 66, 507-518, 2002.

Well, R., Becker, K. W., Langel, R., Meyer, B., and Reineking, A.: Continuous flow equilibration for mass spectrometric analysis of dinitrogen emissions, Soil Sci. Soc. Am. J., 62, 906-910, 1998.

Well, R., Augustin, J., Meyer, K., and Myrold, D. D.: Comparison of field and laboratory measurement of denitrification and $\mathrm{N}_{2} \mathrm{O}$ production in the saturated zone of hydromorphic soils, Soil Biol. Biochem., 35, 783-799, doi:10.1016/s0038-0717(03)00106-8, 2003.

Well, R., Höper, H., Mehranfar, O., and Meyer, K.: Denitrification in the saturated zone of hydromorphic soils-laboratory measurement, regulating factors and stochastic modeling, Soil Biol. Biochem., 37, 1822-1836, doi:10.1016/j.soilbio.2005.02.014, 2005.

Well, R., Eschenbach, W., Flessa, H., von der Heide, C., and Weymann, D.: Are dual isotope and isotopomer ratios of $\mathrm{N}_{2} \mathrm{O}$ useful indicators for $\mathrm{N}_{2} \mathrm{O}$ turnover during denitrification in nitratecontaminated aquifers?, Geochim. Cosmochim. Acta, 90, 265282, doi:10.1016/j.gca.2012.04.045, 2012.
Wessolek, G., Renger, M., Strebel, O., and Sponagel, H.: Einfluß von Boden und Grundwasserflurabstand auf die jährliche Grundwasserneubildung unter Acker, Grünland und Nadelwald., Z. f. Kulturtechnik und Flurbereinigung, 26, 130-137, 1985.

Weymann, D., Well, R., Flessa, H., von der Heide, C., Deurer, M., Meyer, K., Konrad, C., and Walther, W.: Groundwater $\mathrm{N}_{2} \mathrm{O}$ emission factors of nitrate-contaminated aquifers as derived from denitrification progress and $\mathrm{N}_{2} \mathrm{O}$ accumulation, Biogeosciences, 5, 1215-1226, doi:10.5194/bg-5-1215-2008, 2008.

Weymann, D., Geistlinger, H., Well, R., von der Heide, C., and Flessa, $\mathrm{H}$.: Kinetics of $\mathrm{N}_{2} \mathrm{O}$ production and reduction in a nitratecontaminated aquifer inferred from laboratory incubation experiments, Biogeosciences, 7, 1953-1972, doi:10.5194/bg-7-19532010, 2010.

Wirth, K.: Hydrogeologisches Gutachten zur Bemessung und Gliederung der Trinkwasserschutzgebiete für die Fassungen Hagel, Sage und Baumweg, Wasserwerk Großenkneten (OOWV). Beratungsbüro für Hydrogeologie (Hrsg.)., Göttingen, Germany, 18 S., 1990. 